\title{
El mensaje de los mitos: Héroes fundadores y origen de los alimentos en la memoria de los pueblos andinos
}

\author{
Román Robles Mendoza \\ hermanovallejo@hotmail.com \\ Departamento de Antropología. UNMSM
}

\begin{abstract}
Resumen
En este trabajo se reunen y reinterpretan los discursos míticos más representativos de la región centro-andino del Perú, recogidos por los curas encomendados de ejecutar la política eclesiástica de "extirpación de idolatrías" del siglo XVII, como consecuencia del fracaso de más de un siglo de conversión de indios al catolicismo. Francisco de Ávila, Bernardo de Novoa y otros extirpadores de idolatrías confirman la tenaz resistencia ideológica de los indígenas de Huánuco, Cajatambo, Huarochirí, Végueta, que continuaban practicando sus ideas y creencias, ceremonias y ritos a sus deidades, al mismo tiempo que simulaban haberse convertido en creyentes de la religión europea. A partir de la reproducción de las versiones ya publicadas de mitos sobre el origen de los dioses, de los grupos étnicos, de los alimentos y de los manantiales, se analizan y reinterpretan en sus significados y mensajes.
\end{abstract}

Palabras clave: Mitos andinos, Memoria colectiva, Resistencia ideológica, Dioses andinos, Vichama, Mama Rayguana.

\begin{abstract}
In this work join and reinterpret the legendary mythics more representative of the central-Andean region from Peru, collected by the priests assigned to execute the ecclesiastical policy of "removal of idolatries" of the seventeenth century, as a result of the failure of more than a century conversion of Indians to Catholicism. Francisco de Avila, Bernardo de Novoa and other idolatries removers confirm the tenacious resistance ideological by indigenous people of Huanuco, Cajatambo, Huarochiri, Vegueta, which continued practicing their ideas and beliefs, rites and ceremonies to their deities, while simulating having become a believer of the religion of Europe. From the reproduction of already published versions of myths about the
\end{abstract}


origin of the gods, ethnic groups, food and springs, are analysed and reinterpreted in their meanings and messages.

Keywords: Myths Andean, Collective memory, Resistance ideological, Andean Gods, Vichama, Mama Rayguana.

\author{
“... las formaciones nebulosas que \\ se condensan en el cerebro de los hombres \\ son sublimaciones necesarias de su proceso \\ material de vida, proceso impíricamente \\ registrable y sujeto a condiciones materiales... \\ No es la conciencia la que determina la vida, \\ sino la vida la que determina la conciencia." \\ C. MarX y F. Engels: La ideología alemana.
}

\title{
Mitos y memoria colectiva
}

El mito es una narración real y fantasiosa de algún acontecimiento ocurrido en un pasado nebuloso. Es una forma de relato de la historia ocurrida del que se pretende guardar memoria a fuerza de repetirla de generación en generación. Por su función altamente conservadora, el mito viene a ser una literatura de las sociedades y culturas ágrafas (sin escritura), un arte de narrar acontecimientos preconcebidos, con el propósito de que toda la comunidad internalice y haga suya el relato como una verdad heredada de los antepasados, que contribuye a dar coherencia a la forma de vida que practican, la misma que se deriva del mensaje expresado en el contenido del mito. Leyenda y mito son dos conceptos que expresan hechos del pasado remoto, pero tienen sus propias acepciones. Por leyenda se entiende a hechos y personajes históricos reales que han ocurrido o vivido en el pasado no muy lejano de la vida de las sociedades; se guarda memoria de ellos con cierta precisión pero también con agregados más o menos fantasiosos que dan sentido a la fuerza y al poder de realización de prohombres fundadores o de acontecimientos heroicos que dieron origen a las estructuras de la sociedad en referencia. El mito va más allá de la leyenda, es el relato de un tiempo más remoto y nebuloso, donde los hechos y los personajes se confunden con lo real y lo sobrenatural. Actúan fuerzas poderosas suprahumanas, divinidades dotados de poderes, concebidas por los grupos humanos, que interactúan con los seres vivos, en beneficio del orden social de ellos. Sin embargo, no existe una línea divisoria precisa y clara de la diferencia entre leyenda y mito, en muchos casos las leyendas se confunden con los mitos, como también los mitos están entremezclados con los relatos legendarios, tanto como los cuentos y las historias legendarias.

Historiadores y antropólogos han dado cuenta de muchos relatos míticos de los universos donde han estudiado. Por estos datos de las ciencias sociales modernas tenemos una idea clara de que todas las sociedades han construido la parte más remota de su historia apoyándose en los relatos orales de transmisión continua: leyendas, mitos, historias verbales. Estudios antropológicos sobre este campo fecundo de la superestructura de los pueblos son abundantes, tanto en los escritos de los iniciadores de esta ciencia social como en las publicaciones posteriores. Los historiadores coinciden que fue Hesíodo ${ }^{1}$ el primero en ocuparse acerca de los mitos y de su papel en la vida y la compleja cultura de los

1 Hesíodo fue el escritor y poeta que recopiló los antiguos mitos griegos y ordenó en su obra Teogonía la clasificación y jerarquización de dioses y semidioses del siglo VIII a. C. 
griegos de su tiempo. En su obra aparecen las deidades de la creación del cosmos, del hombre y de los elementos culturales creados por él. En la escena de los tiempos modernos, probablemente Sir James Frazer ${ }^{2}$, con su monumental obra La rama dorada ha realizado la mejor contribución a los estudios de la mitología, la magia y la ciencia. Frazer recopila mucha literatura tradicional de los pueblos de Europa y de otras sociedades y culturas del mundo para explicar el pensamiento animista y politeísta de las sociedades antiguas y dar coherencia a sus propuestas sobre las creencias de los pueblos primitivos, cuya publicación original llegó hasta doce tomos. Es este autor escocés quien describe e interpreta, con datos recogidos en distintas partes del mundo, a los dioses creadores del universo, a las muchas divinidades que interactúan con los hombres y a la sacralización de los animales y de las plantas hechas en las distintas culturas. Otros antropólogos clásicos como Tylor en Inglaterra, Boas en los Estados Unidos y Durkheim en Francia han contribuido con el estudio de la mitología en distinta medida, vinculándolo al proceso de construcción del universo religioso como lo hace Durkheim o como un fenómeno cultural recurrente de las sociedades precoloniales como analiza Franz Boas. Quien se ocupa del mito con mayor profundidad es el antropólogo francés Lévi-Strauss ${ }^{3}$. Para el creador del estructuralismo, el mito es un relato mucho más complejo de lo que literalmente aparenta. Es una estructura compleja que mediante procesos de simplificación y simbolización de sus elementos guarda un contenido que va más allá de la simple comprensión del mensaje lingüístico. Por esta complejidad de la estructura del mito, el antropólogo tiene que penetrar en su lectura, visible y oculta, tal como lo entiende Clifford Geertz cuando habla de descifrar códigos en la descripción densa. Como señala Kirk, los mitos pueden revelar estructuras en "distintos niveles" o en "diferentes códigos". Así, en el relato de "La historia de Asdiwal", recogido por Franz Boas, encuentra un nivel de explicación sociológica y también códigos que denotan distintos significados que deben ser interpretados desde la perspectiva estructural. Aun cuando el modelo estructural del análisis de los fenómenos sociales y culturales han tenido y tienen sus cuestionamientos desde otros enfoques, en las obras de Lévi-Strauss hay mucho material mitológico de por medio. Especialistas de las religiones primitivas, orientalistas y antropólogos de diversas tendencias como Jacobsen, Jensen, Kramer, LevyBruhl, Birket Smiht, Malinowsky, Mauss, Eliade, son algunos de los estudiosos que se han ocupado del mito como uno de sus temas especializados.

Hasta antes de la aparición de las grandes religiones monoteístas todas las sociedades han explicado y explican la naturaleza de las cosas, de los fenómenos naturales, de las construcciones culturales, incluyendo su propia existencia, por el mensaje mitológico o el legendario. Por esta razón, el relato mítico antecede al relato religioso monoteísta. Pertenece a la fase evolutiva del politeísmo ${ }^{4}$, antes de la aparición del monopolio ideológico que trajeron consigo las grandes religiones modernas. Cada sociedad, incluidas las sociedades desarrolladas de nuestra época, ha pasado por la fase del pensamiento politeísta, en la que rendían culto a varios dioses jerarquizados: dioses mayores, dioses intermedios y dioses menores o locales. Por esta razón, existe mucha literatura escrita o transmitida verbalmente, en todo el continente europeo, en Oriente Medio y en sociedades de otros continentes, sumergido por debajo de la estructura de la ideología cristiana en sus distintas formas, del Islamismo y de otras religiones monoteístas, difundidas desde su implantación

2 James George Frazer, en La Rama dorada, 1890, establece la secuencia del pensamiento humano entre la magia, la religión y la ciencia.

3 Claude Lévi-Strauss, Antropología estructural, 1958; El pensamiento salvaje, 1964; Mitológicas I, II III y IV: 1964 - 1981; Mito y significado, 1987.

4 E. B. Tylor, en su Cultura primitiva (1871), siguiendo la teoría darwiniana, establece la secuencia evolutiva del pensamiento religioso de la humanidad en las fases: animismo, politeísmo y monoteísmo. 
en Roma, en la Meca y en sociedades como la India y la China, desde hace poco más de dos mil años para el cristianismo y en el mundo árabe cerca de mil cuatrocientos años ${ }^{5}$. Aún cuando las religiones monoteístas han alcanzado amplia hegemonía en el mundo, los relatos míticos no han desaparecido. Continúan en el sustrato cultural de los pueblos, para darle explicación complementaria a muchas formas de racionalidad de los fenómenos naturales y culturales, en estado de superposición con la explicación divina de las religiones monoteístas, naturalmente en franca oposición del pensamiento científico de nuestra época. Los relatos míticos, son por eso, una forma de la religiosidad de las sociedades, que antecede históricamente al pensamiento religioso moderno.

Probablemente, los griegos han erigido con extraordinaria genialidad los relatos míticos, para explicar y fundamentar su historia, sus hechos, sus hazañas, sus virtudes, sus grandezas y flaquezas como habitantes de la tierra. Desde las extraordinarias historias épicas de Homero y los poemas y escritos primigenios de Hesíodo ${ }^{6}$ hasta la vida cotidiana de la Grecia clásica, el panteón sagrado de los helenos estuvo enormemente nutrido de dioses principales ${ }^{7}$, hijos de ellos con poderes para actuar en el mundo de los dioses y en el mundo de los hombres; muchos semidioses, ninfas, musas, titanes, cíclopes y pitonisas que poblaban el universo cultural griego. En la Iliada y la Odisea atribuidos al poeta Homero están entrelazados los relatos históricos y relatos mítico religiosos, donde los héroes de la guerra contra Troya y el retorno de Ulises a su isla de Ítaca, alcanzan mayor belleza con la intervención de la voluntad de los dioses y semidioses del Olimpo: Zeus, Atenea, Artemisa, Poseidón y otros en las acciones y designios de los principales personajes de dichas obras, tales como Paris, Helena, Agamenón, Aquiles, Príamo, Ulises. Dioses y diosas, como los hombres y las mujeres de carne y hueso, tienen sus deseos, preferencias, ambiciones, odios, rencores, amores y celos, que se manifiestan en el accionar de los hombres. La existencia de ambos está en íntima relación entre ellos mismos: las divinidades se emocionan, montan en cólera, castigan, se enamoran y conciben descendientes entre los humanos. Los hombres convocan a los dioses para lograr sus hazañas, les rinden cultos especiales mediante complejos rituales y sacrificios de animales en honor a las deidades preferidas. Se establece entre ellos una estrecha relación e interacción, sin las cuales no tienen existencia armoniosa. En general, los griegos han creado muchísimos relatos míticos de origen, sobre la belleza, la fuerza, las creaciones literarias, los instrumentos musicales. Herodoto, uno de los insignes historiadores y etnógrafos del siglo V a.C. dedica sus nueve libros de historias a las nueve musas de la inspiración; Orfeo estuvo a punto de conseguir la liberación con vida de su amada Eurídice, muerta por la picadura de una serpiente, de las profundidades de los infiernos tocando la dulce lira, pero un error del mandato de Hades frustra su más caro anhelo. Otros mitos, como la de Edipo y la esfinge de Tebas, de Perseo y la medusa, de Sísifo, son otros tantos relatos del mundo helénico. Éstos forman parte de la ingeniosa y abundante mitología de la literatura de Grecia clásica.

Sin duda, los griegos construyeron la síntesis de la cultura de la antigüedad. Crearon y sistematizaron los mitos, las artes, las ciencias y el humanismo en general. Buena parte de sus conocimientos se nutren de otras sociedades y culturas mucho más antiguas que la de ellos: babilonios, asirios, akadios, persas, medos, egipcios, es decir, de la cultura mesopotámica y nilótica fundamentalmente. Muchos mitos mesopotámicos tuvieron influencia en la concepción religiosa de los helenos, como advierte $\mathrm{Kirk}^{8}$, tanto por sus

5 La religión monoteísta islámica fue implantada en la Meca por Mahoma en el año $622 \mathrm{~d}$. C.

6 Hesíodo, Teogonía, en la que describe la naturaleza y la genealogía de los dioses del Olimpo.

7 Zeus y Hera fueron para los griegos los dioses mayores del Olimpo. Zeus era hijo de Cronos y Rea, según la clasificación de Hesíodo.

8 C. S. Kirk, El mito: su significado y funciones en las distintas culturas, Barral editores, 1973. 
contenidos como por sus similitudes. La transcripción de las muchas escrituras antiguas, encontradas en las denominadas tablillas da cuenta de la rica literatura mítica de las culturas que se desarrollaron entre los riós Tigris y el Eufrates. En el mito sumerio de Enki y Ninhursag situado en Dilmun, tierra desértica, aparecen creaciones necesarias para la vida. Enki dios del agua hace brotar el líquido elemento del desierto a solicitud de su esposa Ninsikilla; engendra una hija en Nintu o Ninhursag, madre de la tierra, que en nueve días da a luz a Ninmu. También ella es embarazada por Enki y da a luz otra hija que se llamará Ninkurra, quien vaga por los pantanos y es igualmente embarazada para dar a luz a Uttu. Es precisamente Uttu quien pide a Enki que le traiga frutos y Enki irriga los campos para cultivarlos y llevar frutos a Uttu, quien es igualmente embarazada por Enki, pero Ninhursag le saca la simiente para ponerlo en su seno. Ninhursag maldice y le saca los ojos a Enki, que enferma en ocho partes, de cuyas heridas salen ocho plantas distintas. La enfermedad de Enki produce sequía y hambruna porque este dios es símbolo de creación de la agricultura y de la fertilidad en un mundo desértico. La fertilidad femenina de la sucesión de mujeres y la fertilidd de la tierra están unidas en este mito. Otro de los mitos representativos de creación de la cultura akadia, es conocido como Enuma Elish, que cuenta cómo el dios babilonio Marduk logra vencer a Tiamat y con sus partes crea el cielo y la tierra, luego crea y ordena el universo a partir del caos y crea al hombre. En este largo poemario, intervienen varias divinidades, tales como Ea, Anu, Enlil dios de los vientos, pero es Marduk el dios creador del universo y del hombre, creador también de la cultura mesopotámica y de las ciudadesestado primigenias como Uruk, donde se construyó el templo o sigurat en su honor ${ }^{9}$. Otras historias orales hecha poesía epopégica como la de Enkidu y Gilgamesh, creadores de la domesticación de plantas; de Sharur, Asag y Nirurta, manipuladores del agua en las tierras áridas, que luego el Tigris inunda, y muchos otros relatos míticos de babilonia, sumeria, akadia $^{10}$, explican el origen de las ciudades y el ordenamiento de la sociedad alrededor del fértil mundo mesopotámico, de donde nace la idea del edén en la Biblia judeocristiana. En estos relatos orales, los dioses y los hombres y hasta las ciudades entran en disputas, amores, luchas y competencias.

En esa misma perspectiva, la rica mitología egipcia, signada por el desarrollo de una cultura dependiente del crecimiento y la disminución del caudal del río Nilo tuvo que influir en la construcción de la síntesis cultural griega. Para los estudiosos de la cultura egipcia, el relato mítico más representativo es el de Osiris e Isis. Este mito proporciona la más lejana referencia de la fundación del pueblo egipcio en la figura mítica de Ra que simboliza al dios sol. Según este relato de origen, el dios Ra tuvo una hija llamada Nut, diosa de los cielos. Geb, dios de la tierra se enamoró de Nut, pero al enterarse su padre Ra de esta relación con Geb le prohibió concebir hijos durante los 360 días del año. Geb recurrió a su amigo Thot para que con la participación de Selene, diosa de la luna, pudiera ayudarle en sus amoríos con Nut. Fue así que la luz que irradiaba Selene, al entrar en estado menguante, desapareció por cinco días, que fue motivo para que se adicionaran a los 360 días del año. Durante esos cinco días Nut concibió cuatro hijos: dos varones Osiris y Set, y dos mujeres Isis y Neftis. Al crecer Osiris se hizo rey de los egipcios y desposó con su hermana Isis. Fueron ellos, Osiris e Isis, los verdaderos héroes fundadores de la cultura egipcia: enseñaron el arte de la agricultura en los campos húmedos que dejaba el Nilo cuando bajaba de caudal, el arte de domesticar y criar ganado, así como vivir dentro de un orden social debidamente organizado. Por ser divinidades descendientes del dios Ra fueron respetados y adorados, por lo que su envidioso hermano Set, dios de la noche, de la oscuridad

9 Citado por Kirk, p. 111.

10 Ob, cit: p. 119. 
y del mal, tejió una estratagema para dar muerte a Osiris. Logró su objetivo organizando un gran banquete, en cuyo acto Osiris fue encerrado en un féretro de oro y luego echado a las aguas del río Nilo. Enterada de la desgracia, Isis lo buscó por todas partes y con la ayuda de unos niños encontró el cadáver de su amado esposo, lo mandó embalsamar y le dio digna sepultura. El mensaje de este mito dio lugar para que en Egipto se erigieran los más espectaculares sepúlcros de mandatarios como son las famosas pirámides y se comenzó a practicar el arte del embalsamamiento de los cuerpos de los dignatarios muertos. Por estas historias míticas de extraordinario significado de la Mesopotamia, de Egipto, de la India, de China y de todas las sociedades y culturas del mundo antiguo podemos encontrar la explicación ideológica real y fantasiosa de los orígenes de la agricultura, del sistema de riego, de la fundación de las ciudades y del ordenamiento social del universo de los hombres. Muchas de estas formas de expresión literaria oral de la antigüedad, tuvieron que influir en la compleja y extraordinaria cultura griega, de la que se han ocupado muchos autores europeos y americanos. Los relatos míticos constituyen el punto de partida para reconstruir la historia de las sociedades y son al mismo tiempo los elementos embrionarios del pensamiento religioso de los pueblos.

No sólo en las sociedades y culturas originarias del mundo europeo se han construido los relatos míticos para fundamentar el origen y la naturaleza de los grupos humanos y de las cosas de su entorno, las sociedades del mundo americano también tienen lo suyo para dar sentido a los mismos fenómenos referentes a la vida de la especie humana. Desde los estudios iniciados por Lewis Morgan ${ }^{11}$ entre los iroqueses hasta los minuciosos trabajos hechos por el antropólogo alemán Franz Boas y sus discípulos se ha acumulado mucho material sobre mitos y leyendas de las muchas tribus originarias que poblaron los territorios actuales del Canadá y los Estados Unidos, incluyendo Alaska. De México conocemos la abundante literatura oral prehispánica por las crónicas de la Colonia. Especialmente, la obra del franciscano Bernardino de Sahagún ${ }^{12}$ y Popol Vuh $h^{13}$ de autor anónimo, atesoran la abundante y extraordinaria mitología azteca y maya. Aparecen en la mitología mexicana las deidades creadoras del universo, de los hombres, de los alimentos como el maíz, de la agricultura y del orden social impuesto por los héroes fundadores, como Quetzalcóatl y los cuatro hijos de Quetzalcóatl y Huitzilopochtli, que dan coherencia civilizatoria a los grupos humanos desde su forma primitiva y salvaje. En el subcontinente sudamericano, la cultura andina que se gesta a partir de la inclusión de varias sociedades que poblaron la faja costera, las estribaciones de la cordillera de los Andes y la Amazonía, dan lugar a la formación del Tahuantinsuyo, bajo el dominio de los quechuas cusqueños. También en esta cultura andina, la memoria colectiva conservaba y sigue conservando el relato mítico y legendario para explicar sus orígenes y racionalizar su vida social y cultural en un medio geográfico difícil de dominar. Cronistas como Garcilaso, Cristóbal de Molina, Polo de Ondegardo, Antonio de Calancha, Felipe Guaman Poma de Ayala y sacerdotes dedicados a la extirpación de idolatrías como Francisco de Ávila ${ }^{14}$, Rodrígo Hernández

11 Lewis Morgan recogió en sus escritos etnográficos versiones de mitos de origen de las tribus que conformaban la Liga de los Iroqueses y los abundantes ritos que le dedicaban a sus dioses y a sus fetiches.

12 La monumental obra Historia general de las cosas de Nueva España, escrita en lengua náhuatl, es el mejor testimonio de la cultura azteca recogido directamente de los sabios nativos de la época.

13 El extraordinario libro conocido como Popol Vuh fue reconstruido y traducido de la lengua quiché de Guatemala al castellano por el dominico Fray Francisco Ximénez a principios del siglo XVIII. El austriaco Carl Scherzer, lo volvió a publicar en Viene en 1857 bajo el título original de Las historias del origen de los indios de esta provincia de Guatemala. El título de Popol Vuh, como se le conoce desde entonces, se debe a la edición hecha por el americanista francés Charles Étienne Brasseur, París, 1861.

14 Francisco de Ávila, cura de San Damián, recopiló el conjunto de mitos que hoy se conocen bajo el título de Dioses y hombres de Huarochirí, traducido del quechua por José María Arguedas en 1966. 
Príncipe o Bernardo de Noboa, recopilaron la abundante literatura oral en la que los mitos y leyendas constituyen un capítulo importante. Por estos relatos reales y fantasiosos tenemos información acerca de los dioses y héroes fundadores, como Naylamp, Catequil, Libiac Cancharco, Vichama, Mama Rayguana, Con, Huiracocha, Pachacamac, Manco Cápac y Mama Ocllo. Aquí también, unos aparecen como dioses creadores, otros como héroes civilizadores que dieron estatuto de vida racionalmente ordenada y organizada, siempre con una estricta relación de reciprocidad y armonía con la naturaleza, la pacha mama.

Por su misma naturaleza, los relatos míticos cumplen en las sociedades ágrafas la función de explicar y dar sentido al origen del universo, de la naturaleza, del hombre y de las cosas y dar coherencia racional a las relaciones sociales y la construcción cultural de cada una de las sociedades. Son relatos ordenadores de la vida cotidiana, de las costumbres, de las creencias, fundadas en discursos muy bien organizados. Los mitos pueden estar relacionados o no con los ritos, pueden tener parentesco o no con el pensamiento religioso, pero tienen en común la participación de actores con poder y capacidad de hacer cosas que el común de la gente no lo puede: dar sentido a las construcciones culturales de las sociedades, antes de la hegemonía de las religiones monoteístas y antes de la racionalidad de la ciencia concreta. Los mitos son uno de los referentes literarios orales de las sociedades elementales que ayudan a interpretar -a su manera- la lógica de las formas culturales que estudiamos los científicos sociales en contextos diferentes.

\section{Dioses y héroes fundadores del antiguo Cajatambo}

\section{Represión y memoria colectiva}

Por la sólida memoria de los yachaj (conocedores, sabios) del siglo XVII tenemos abundante información sobre el origen de los dioses principales y de sus hijos, que aparecen como héroes fundadores de grupos étnicos de la región centro andina del Perú. Estas informaciones nos han llegado por los resultados de la persecución y destrucción de ídolos sagrados de la política denominada "destrucción de idolatrías" emprendida por el Arzobispado de Lima, por mandato de los Concilios Limenses ${ }^{15}$ celebrados en Lima durante el siglo XVII. Varios Arzobispos de Lima contribuyen en implementar y ejecutar los acuerdos de los Concilios Limenses: Jerónimo Loayza, Toribio de Mogrobejo, Lobo Guerrero, Gonzalo de Ocampo, Hernando Arias de Ugarte y Pedro de Villagómez. Los primeros Arzobispos implementaron los mecanismos de la persecución y represión ${ }^{16}$ sobre los cultos religiosos andinos, preparando las Instrucciones y creando un conjunto de normas a ser aplicadas en los procesos de destrucción de ídolos sagrados. Desde Lobo Guerrero hasta el más insistente impulsor de visitas del gobierno del Arzobispado de la Ciudad de los Reyes por Pedro de Villagómez, se ejecutaron sendas visitas de persecución, represión y ajusticiamiento de indios en los mismos escenarios donde comparecen ante los visitadores. La tarea de destrucción de ídolos y sentencia de idólatras la ejecutaron los curas visitadores expresamente nombrados por el Arzobispado de Lima, quienes viajaron hacia distintos puntos de la Colonia con el encargo estricto de identificar y castigar a los cultores de ritos religiosos prehispánicos, destruir públicamente los ídolos sagrados, mallquis y símbolos

15 El Arzobispado de Lima organizó tres principales Concilios Limenses en el siglo XVI: Primer Concilio en 1551, Segundo Concilio en 1567 y Tercer Concilio en 1587.

16 Ejemplares castigos y duras condenas a los cultores de la religión andina fueron implementadas por las Instrucciones del Arzobispo limeño Gerónimo Loayza y las Constituciones de Lobo Guerrero: paseo público, desnudo y montado sobre una llama con la cabeza rapada, servicios gratuitos en los curatos locales, azotes en la plaza pública, encarcelamiento, confiscación de sus bienes, etc. eran algunos de los castigos. La mayor condena que recibía un sacerdote andino era ser enviado como remero a las galeras del Callao. 
identificados con el culto religioso no cristiano. Cada visitador eclesiástico iba acompañado de un séquito de personas que cumplían distintos papeles en la tarea de destruir ídolos e idolatrías: un fiscal, un notario, uno o dos sacerdotes de alguna orden, preferentemente jesuitas, un indio o mestizo castellanizado como traductor de la lengua de los habitantes de cada región, un secretario encargado de registrar las declaraciones textuales de los encausados y ayudantes. En esta colosal campaña idolátrica participaron conocidos sacerdotes como Francisco de Ávila (Cura de San Damián, primer visitador de idolatrías en Huarochirí, enviado por Lobo Guerrero: 1609), Cristóbal de Albornoz (Persiguió los ritos del Taki Onqoy en la provincia de Huamanga: 1569-1571), Rodrigo Hernández Príncipe (Cura de la doctrina de Ocros, se encargó de dar cuenta de las idolatrías de la región norte de Cajatambo: 1622), Fernando de Avendaño (Primer visitador de la provincia de Cajatambo, nombrado en 1617), Bernardo de Noboa (Cura de la doctrina de Ticllos, que persiguió a los sacerdotes andinos de buena parte de Cajatambo, actuales provincias de Bolognesi y Ocros: 1656-1664) y muchos otros. De esas visitas se acumularon muchos manuscritos coloniales. Mediante estos valiosos documentos que, felizmente se conservaron en el Archivo Arzobispal de Lima, podemos reconstruir algunos aspectos de la historia de los grupos étnicos, de sus ideas y creencias, sus rituales, su organización social, su economía y otros elementos que se encontraban funcionado plenamente durante la ocupación española del Tahuantinsuyo y continuó practicándose durante el pleno dominio colonial de los peninsulares. La mitología de los héroes fundadores, el origen de los pueblos y de los principales productos que consumían, de las que tratamos en este artículo, están basadas en los datos que proporcionan los yachaj, que desfilan delante del visitador eclesiástico a esta región, cuyas traducciones han sido hechas por distintos estudiosos ${ }^{17}$ de la segunda mitad del siglo XX. Evidentemente, este material recogido por los visitadores, por la fuerza de la represión, no es sino fruto de la memoria colectiva que conservaban los yachaj del antiguo Cajatambo, casi un siglo y medio después de la invasión y asalto de Cajamarca por los conquistadores españoles.

\section{Origen mítico de la etnia de los huaris}

Cuando los visitadores de extirpación de idolatrías recorrieron pueblos a la caza de sacerdotes andinos e ídolos sagrados del pensamiento religioso prehispánico, a quienes llamaban "hechiceros", "brujos", "dogmatizadores", "ministros abominables del demonio", no solo preguntaron a los indios procesados sobre sus creencias, sus divinidades, sus ritos y los bienes que poseían, preguntaron también acerca de los orígenes de pueblos y de sus antepasados. Por esta razón, en la ya abundante publicación de los documentos de estas visitas persecutorias de las creencias de los naturales andinos, se encuentra mucho material recogido de la memoria colectiva de la época. Lo interesante es que todos los entrevistados coinciden que proceden de dos grupos étnicos diferentes y opuestos en sus modos originarios de existencia: los yaros o llacuaces, habitantes de las alturas que vivían de la caza y del pastoreo de camélidos sudamericanos, y los huaris o waris, habitantes de las zonas medias y bajas, que se sustentaban de los productos de la agricultura. Por otro lado, las informaciones que dan los procesados, establecen que los huaris vinieron del sur andino, del Titicaca y los llacuaces proceden de las altiplanicies del Bombón, pero al mismo tiempo, explican también que ambos grupos étnicos se establecieron en el mismo espacio adyacente a la cordillera Huayhuash, cuyas montañas nevadas más representativas de esta cordillera blanca, Racco y Yerupajá, aparecen como las pacarinas de las deidades

17 Para los documentos relativos a la extirpación de idolatrías en Cajatambo, son notables las traducciones y publicaciones hechas por Lorenzo Huertas (1981) y Pierre Duviols (1986), además de otros. 
fundadoras de las dos culturas que antecedieron a los incas en esta parte del territorio centro andino. La explicación mítica de los orígenes de huaris y llacuaces, contados por los yachaj de mediados del siglo XVII se entrecruzan en los mismos espacios donde fijaron sus habitat especializados primero, para luego fusionarse y formar una sola nación ${ }^{18}$, tal como lo conquistaron los incas en el siglo XV.

Las ocho ventanas del Yerupajá. Don Andrés Chaupis Yauri, un extraordinario yachaj del ayllu de Otuco, explica con mucha claridad el origen mítico de los huaris, en su declaración del 5 de julio de 1656, ante la pregunta del visitador Bernardo de Noboa. La parte explicativa de su declaración es la siguiente:

“... a oido deçir a sus pasados (antepasados) que los dhos Guaris primero eran hombres de nacion gigantes barbados y que su origen fue el Yerupaxa que es un cerro grande nevado que esta en la cordillera arriba de Mangas y tiene ocho puertas de grandes cuebas y que de ellas salieron los guaris muchos a unas partes y a otras y que los que uinieron a este dho pueblo llegaron a Yumay Purac que esta arriba de Mangas en la cruz y desde alli uinieron a Cussi llaclla Canis y Guamgri por abajo de Raham y que tienen un apo que los crio y estos adoran al sol por su padre y en Guamgri tienen dos mallquis destos guaris llamados Yana Ambra a estos adoran cuatro ueces al año una antes de Nauidad para limpiar las azequias y entonces de Otuco se embiaban cuies coca mollo sebo plumas del Hasto Tucto por henero haçian honrras a los dhos Libiac... (Declaración de Andrés Chaupis Yauri, publicado por Duviols, 1986:55)

La historia de los huaris, contada de generación a generación, da cuenta que estos agricultores vinieron del Titicaca, donde fueron criados por el sol su padre, como manifiesta Domingo Rimachi. Tanto Chaupis, Rimachi y otros informantes están de acuerdo que los huaris fueron de alta estatura, "gigantes" y que también eran "barbados" y que eran adoradores del sol como su dios creador. Pero el origen mítico de los huaris contado por Andrés Chaupis, explica que son hijos del nevado Yerupajá, la montaña más importante del Huayhuash. El Yerupajá, dice Chaupis, "tiene ocho puertas de grandes cuevas" y que "de ellas salieron los guaris". Si los huaris salieron de las ocho cuevas del Yerupajá, se entiende que son hijos de esta emblemática montaña. El informante no lo dice, como tampoco dirá acerca del origen de los llacuaces. En cambio, don Andrés es claro en afirmar que los héroes fundadores de los huaris salen de esa múltiple pacarina "ocho puertas ... del Yerupaxa", hacia todas las direcciones, es decir, "muchos a unas partes y a otras" a fundar pueblos. Un grupo de ellos, "los que uinieron a este dho pueblo" lo hicieron apeándose en Yumay Parac, un paraje que está ubicado en la parte alta de Mangas, donde efectivamente los españoles plantaron una cruz. Hasta hoy hay allí una cruz que se ve de Mangas, a cuya cumbre llaman ahora Cerro San Cristóbal, a semejanza del San Cristóbal del valle del Rímac. Y “desde allí” vinieron a distintos pueblos, fundaron pueblos de agricultores que perduraron por mucho tiempo y algunos de ellos siguen existiendo con sus mismos nombres: Cussi, Llaclla, Canis y Guamgri. Tres de estas poblaciones de zona quichua semicaliente y de economía agrícola siguen hasta hoy, con sus nombres actuales: Llaclla, Canis y Huanri. Cusi ha desaparecido como pueblo, pero sus ruinas son conocidas, situadas entre Corpanqui y Llaclla de la actual provincia de Bolognesi. Según el declarante, los mallquis de estos héroes fundadores huaris se encuentran en cada uno de los ayllus fundados, pero menciona a sólo uno: a Yana Ambra que está en Guangri y que le rinden culto cuatro veces al año "una antes de Nauidad" otra en "henero". Luego relata la pompa con que se hacían las celebraciones al mallqui del héroe fundador, con cuyes, mullu, sebo, coca, plumas coloridas de aves; también durante la limpia acequia de Huanri, con la participación de los indios de Otuco que bajaban con sus

18 La idea de oposición y complementariedad de estas dos etnias corresponde a Duviols (1973). 
ofrendas. Casi cuatro siglos después de esos eventos, los campesinos actuales de Huanri continúan haciendo la limpia acequia, entre rituales y faena, dos días después de la fiesta patronal de la Virgen de la Natividad: el 12 y 13 de setiembre limpian el canal de Rauyanca (arriba); el 15 y el 16 de setiembre limpian el canal de Pashiryoc (abajo). Ambas faenas terminan en grandes comelonas y actos rituales que duran toda la noche de los días finales del trabajo en los canales ${ }^{19}$.

Por estas valiosísimas informaciones dadas por la memoria indígena del siglo XVII sabemos que el nevado Yerupajá viene a ser una especie de Olimpo para los huaris y también para los llacuaces. Para los huaris porque sus héroes fundadores salieron de las ocho ventanas de grandes cuevas y para los llacuaces porque su deidad Libiac Cancharco, el dios padre de los héroes fundadores, recorren casi los mismos espacios, cayó del cielo en forma de rayo y se aparecen también por el pueblo de Mangas. Es del Yerupajá, por ser la montaña más alta de la cordillera Huayhuash, de donde salen los truenos y relámpagos, con lo que aparece precisamente el dios Libiac Cancharco. Por eso, para ambos grupos étnicos, el Yerupajá es un símbolo de origen y una pacarina donde nacen los dioses. Los habitantes de hoy ya no le rinden pleitesía como en los tiempos de huaris y llacuaces, pero sigue siendo el símbolo sagrado de todos los pueblos de la región, principalmente para los de Pacllón y Llamac, cuyos linderos llegan hasta el lado occidental del Yerupajá. Su gran altitud, de 6,634 msnm, el segundo pico más elevado del Perú, se yergue reluciente en los días de sol y se le puede ver como un emblema regional desde Raján, Huanri, Llipa, Cajamarquilla, Carhuajara, Corpanqui, Ticllos, Roca, Cuspón, que son las poblaciones de la margen derecha del río Negro (Pativilca). Este gran nevado fue estudiado con mayor precisión por el geógrafo austro-alemán Hans Kinzl, recién el año de 1937, quien estableció definitivamente la altitud correcta de $6,634 \mathrm{msnm}$, que reconocen todos los científicos de la actualidad y explicó la razón del nombre de Huayhuash a esta cordillera que es límite de cuatro provincias de tres departamentos: Cajatambo (Lima), Bolognesi (Ancash), Dos de Mayo y Lauricocha (Huánuco).

\section{Origen mítico de la etnia de los llacuaces}

\section{El dios Yana Ramán o Libiac Cancharco}

Hay distintas versiones divulgadas por varios autores, que describen el origen del dios Yanaramán, que también tiene el nombre de Libiac Cancharco. Augusto Cardich $^{20}$ es quien ha trabajado mejor este tema en sus varios escritos. De su monografía publicada en 1981 extraemos materiales para explicar el origen y la proyección social de Yana Ramán. El primer nombre de esta deidad proviene, según las pesquisas de Cardich, de un antiguo mito que todavía lo cuentan los campesinos de la zona de Lauricocha, como es el caso de don José la Rosa, un personaje que no sólo “...era un ferviente creyente de Yana Ramán, sino un chamán, un verdadero yachac". Según el mito contado por La Rosa, Yana Ramán era un jirca (montaña) de color oscuro, conocido como personaje malo, pero el cerro era muy rico, por la cantidad de ganado que poseía en sus faldas y también muy poderoso y temido, porque había vencido a otros jircas de la región en distintas competencias. El jirca Yana Ramán, situado hacia un extremo de la laguna de Lauricocha, salió victorioso en una feroz contienda entablada con otro jirca llamado Sheguel, el cerro bueno, que originalmente se encontraba en medio de la laguna Lauricocha. El victorioso Yana Ramán,

19 Robles, La banda de músicos, 2000: p. 55-56.

20 Cardich, Dos divinidades relevantes del antiguo panteón centro andino: Yana Ramán o Libiac Cancharco y Raiguana, 1981. 
mata al jirca Sheguel Huamán y lo hunde en la laguna. Desde entonces, sólo queda el oscuro y temido Yana Ramán, convertido en un dios para los creyentes andinos como José La Rosa, "su sacerdote" hasta mediados del siglo XX. Esta deidad montaña sería la misma personificación de Libiac Cancharco, según el estudio de Augusto Cardich.

El nombre de Libiac Cancharco es más conocido, tanto en el lado oriental como en el lado occidental de los Andes. Representa al dios rayo, del que provienen los llacuaces que poblaron esta parte de la sierra central del Perú entre los años 600 a 1400 d.C. Varios testigos de Huánuco y de Cajatambo, que comparecieron ante los visitadores, dieron informaciones explícitas sobre esta deidad altoandina. De las declaraciones del testigo Francisco Marcapari de la localidad de Cauri del ayllu de Yachas (Huánuco), hecha el 9 de marzo de 1615, ante el visitador eclesiástico de idolatrías bachiller Juan Bendiel de Salazar, aparece el primer relato mítico sobre el dios de los yaros o llacuaces, pastores altoandinos de la región central del Perú antiguo. De este informante extraemos esta versión:

“... dijo que lo que sabe i a bisto este testigo como yndio antiguo y a oydo descir a sus antepasados que los yachas encomienda de doña Melchora de las Niebes vecina de la ciudad de Guánuco fundados en este dicho pueblo de cuyo ayllo y parcialidad es este testigo que en los bayles que acen y an hecho de la llaspa en la Upaca en la yrigua y en la llamaya en estos bayles de continuo ynbocan y adoran a Yanaraman al cual le dan por origen que un pueblo llamado guacras que era la parcialidad de los chucas los quales en aquel tiempo eran muchos y que un indio de este pueblo llamado Atunchuca andando a casa de vicuñas y benados en el cerro de rraco que sta en la llanada de bon bon allo una criatura pequeña enbuelta rrescien nacida que desian abia caydo del cielo y como el dicho Atunchuca no tubo hijos tomo el dicho muchacho Yanaraman para criarlo y dentro de cinco dias crescio de suerte que podia apasentar las llamas y como el dicho Atunchuca tenia gran suma de carneros de la tierra en el dicho pueblo de guacra le entrego sus llamas para que el dicho Yanaraman se las apasentase y estando en esta suerte conbirtiendose en leon yba comiendose el ganado y sabido por el dicho Atunchuca que el dicho su ganado yba a menos prometio de darle una buelta y con esto enbio un mensajero al dicho Yanaraman para que biniese con todo el ganado y como el dicho Yanaraman lo entendio llevo todo el ganado y se lo entrego y luego se fue y aunque le llamaban no quiso bolber y aunque el dicho Chuca (sic) las encerro muy bien en el dicho corral se salieron y se fueron tras del // asta un cerro llamado Pumas Catac donde el dicho Yanaraman encontro a sus hermanos llamado Carguapincollo y Carguamachaguay a los cuales el dicho Atunchuca yendo en seguimiento de su ganado allo juntos y el dicho Yanaraman muy enojado le dijo al dicho Atunchuca se fuese y llebase sus llamas y bolbiendolas a su casa el dicho Atunchuca se convirtieron en piedras las quales estan en Yanacallan tres leguas de este dicho pueblo en una llanada pequeña que por otro nombre llaman al dicho Yanaraman Llibiac Cancharco nombre dedicado al rayo y con esto dan a entender que un nombre y el otro es una misma cosa y así el dicho Chuca (sic) es adorado por que crio al dicho Yanaraman y por ello sabe este testigo que todos los yndios de este dicho pueblo de Cauri asi de la parcialidad de este testigo como de la de Juan Sanchez Falcon tienen de costumbre adorar por dios en sus bayles de la llaspa y en los demas que acen a Llibiac Binac Bilca questa media legua de este dicho pueblo poco mas o menos y el origen que los dichos yndios para ello tienen el que en tiempos pasados el lugar donde esta el dicho cerro en una llanada y que en la dicha llanada abia caydo un hombre del cielo y que luego aquella llanada fue creciendo y aciendose un globo grande de que se fundo el dicho cerro el qual dicho ombre que cayo del cielo dejo tres hijos llamados Raria Paucar y Callupa y Nabpara de los cuales se entiende que todos los de este dicho pueblo proceden a los quales y al dicho Binac Bilca han tenido hasta oi por su dios por que an creydo y creen que el dicho Binac Bilca se torno a subir al cielo donde esta el sol de manera // 
que el pueblo que tienen y creen y adoran los yndios deste dicho pueblo como dicho tiene asi antepasados como los que al presente hay a los quales ynbocan de ordinario en los dichos bayles que acen de la llaspa llamandolos santos de dios.....” (Legajo 2, Archivo Arzobispal de Lima, citado por Cardich, 1981).

De las declaraciones contundentes de Francisco Marcapari del pueblo de Cauri se pueden extraer varios comentarios interesantes sobre el origen del dios Yanaramán o Libiac Cancharco, de su vida entre los pastores y de su repentina desaparición, en las llanuras adyacentes del lado oriental de la cordillera Huayhuash:

- Primero: que el indio Atunchuca "andando a casa (caza) de vicuñas y benados en el cerro de rraco" situado en la meseta de Bon Bon o Meseta de Junín, encontró "una criatura pequeña enbuelta rrecien nacida que desian abia caydo del cielo" Atunchuca, que por lo visto era cazador y pastor del altiplano de Bon Bon, sin hijos y sin familia, llevó al niño recién nacido a su casa y lo crió como hijo suyo. Esta criatura fue encontrada "envuelta" en ropas, pero decían (los lugareños) de él que "abia caydo del cielo", por lo que aparece como personaje sobrenatural de nombre Yanaramán o también Yanaramán Libiac Cancharco. Para sorpresa de Atunchuca, el niño creció tan rápido, que a los cinco días ya era un joven que podía dedicarse a apacentar el ganado de su padre adoptivo. Fue entonces que Yanaramán se dedicó cuidar el abundante ganado de Atunchuca.

- Segundo: el indio Atunchuca quien encuentra al bebé recién nacido llamado o dado por nombre Yanaramán era natural del pueblo o ayllu de Guacra y dentro de los pastizales de este pueblo estaba el cerro Racco donde fue encontrado el niño caído del cielo. Este cerro "fue creciendo y aciendose un globo grande de que se fundó dicho cerro". Se refiere al nevado Racco que forma parte de los elevados picos del lado oriental de la cordillera Huayhuash. La ubicación geográfica del pueblo de Atunchuca y del cerro Racco están plenamente identificadas por el informante Marcapari en el proceso que se le siguió en Cauri.

- Tercero: Yanaramán se dedicó a pastar el ganado de su padre adoptivo, pero el improvisado pastor "convirtiendose en leon" se iba comiendo el ganado con tanta voracidad que alarmó al dueño del ganado. Atunchuca encargó por intermedio de un mensajero que Yanaramán volviera a Guacra y entregara el ganado a su cargo. Así lo hizo, entregó todo el ganado, muy molesto, y luego se fue, y "aunque le llamaban no quiso bolber". Atunchuca encerró el ganado en los corrales, pero los animales saltaron sobre los muros y se fueron detrás de Yanaramán.

- Cuarto: Yanaramán llegó hasta el cerro llamado Pumas Catac donde encontró a sus dos hermanos: Carguapincollo y Carguamachaguay. Hasta allí llegó Atunchuca siguiendo a su ganado y los encontró a los tres hermanos. Yanarraman, encolerizado, le increpó a Atunchuca, le indicó que se fuera de inmediato llevándose todo el ganado. Cuando Atunchuca se volvía a su pueblo con el ganado recuperado, vio que Yanaraman y sus dos hermanos se habían convertido en piedras de color oscuras. Estas piedras sagradas están en el paraje de Yanacallán, "que por otro nombre llaman" Yanaramán Libiac Cancharco "nombre dedicado al rayo", situada a tres leguas de Guacra.

- Quinto: el indio pastor-cazador Atunchuca entra a la pléyade sagrada de los llacuaces, por haber criado, a pesar de los incidentes por el ganado, a Yanaramán o Libiac Cancharco venido del cielo, tal como lo manifiesta Francisco Marcapari: "así el dicho Chuca (sic) es adorado porque crió al dicho Yanaraman". Por esta causa, para los llacuaces Yanaramán o Libiac Cancharco es su dios principal y el pastor Atunchuca su semidios.

- Sexto: por los conocimientos del yachaj Marcapari, "todos los yndios de Cauri y de las distintas parcialidades" de la región "tienen por costumbre de adorar por dios" a 
Yanaramán o Libiac Cancharco, se entiende, también a quien lo crió, el pastor-cazador Atunchuca del pueblo de Guacra y al cerro Libiac Binac Bilca, que subió "al cielo donde está el sol", porque representan a sus orígenes míticos.

- Sétimo: Yanaramán o Libiac Cancharco tuvo, según la sabiduría de Francisco Marcapari, tres hijos: Raria Paucar, Callupa y Nabpara. Ellos son los verdaderos héroes fundadores de los pueblos de la región, donde está Cauri en el departamento de Huánuco. No menciona Marcapari a los pueblos que fundaron cada uno de los hijos de Yanaramán, como sí se mencionan en el caso de los hijos de Libiac, narrado por Andrés Chaupis de Otuco.

- Octavo: los rituales dedicados al dios Yanaramán o Libiac Cancharco, a sus hijos héroes fundadores, a Libiac Binac Bilca y a Atunchuca, se hacían con acompañamiento de músicas y bailes. Las músicas y bailes sagrados dedicados a estos dioses y semidioses los recuerda Marcapari y dice que son: la llaspa, la upaca, la irigua, la llamaya. En las ceremonias les "inbocan de ordinario en los dichos bayles que hacen de la llaspa llamandolos santos de dios", tocando sus tamborcillos y pincullos. De estas músicas sagradas queda uno solo: la llaspa o llachpa, que en comunidades como Mangas, Nánis y Chamas, del lado occidental de la cordillera de Huayhuash, cantan y bailan durante la siembra y la cosecha de papas cultivadas en la modalidad de secano ${ }^{21}$.

\section{El Apu Libiac Cancharco en Cajatambo}

Las versiones más variadas sobre Libiac Cancharco, sin la anteposición de Yanaramán, proceden de los yachaj del lado occidental de la cordillera en la región de Cajatambo, que desfilan ante el visitador de idolatrías Bernardo de Noboa, cura de la doctrina de Ticllos que se encargó de destruir muchos ídolos del panteón religioso andino, subsistente aun a mediados del siglo XVII, en buena parte de esta región. Durante los interrogatorios a los sacerdotes, sacerdotizas andinas y a los principales mandones de los ayllus de la región, fluye mucha información valiosa acerca de los rituales religiosos politeístas y también acerca de la historia social y las versiones de la mitología que explican sus orígenes étnicos y sus elementos culturales básicos.

Uno de los yachaj o sabios de la época fue don Domingo Rimachi, natural del ayllu de Allauca del pueblo de Santa Catalina de Pimachi, de la actual provincia de Ocros, quien hace escuetas pero contundentes declaraciones sobre el origen de los "guaris y llaguaces" que poblaron la región Cajatambo antes de la conquista de los incas en el siglo XV. Esta ceremonia de arrancar datos idolátricos a los indios de Pimachi se realizó el 25 de abril de 1656. Por entonces, Domingo Rimachi era Alcalde Ordinario de la localidad. El cargo de Alcalde Ordinario o pedáneo, fue establecido por los españoles en los pueblos de indios a semejanza de lo que en España rural funcionaban por entonces. Sustituyeron a los curacas o pachaca camayoc del sistema político inca en el manejo de los ayuntamientos de estilo peninsular. A la pregunta de si conoce o ha oído decir acerca de sus antepasados los guaris y de dónde vinieron, Domingo Rimachi responde:

“... que oyo decir a sus antepasados que vinieron de Ticicaca que es donde nase el sol y donde fueron criados."

Rimachi es claro al afirmar que los guaris no eran nativos de la zona, habían venido del altiplano surandino y se habían establecido en toda esta región, como lo han confirmado varios autores (Lumbreras, Amat, entre otros). La frase "donde fueron criados" debemos interpretarlo como que "fueron originarios" de la pacarina del Titicaca. Y cuando le

21 Cultivo de tubérculos sin riego, sólo con las lluvias, por lo que se denominan también cultivo temporario. 
preguntan que diga si es verdad que los dichos guaris fueron los primeros pobladores de estas tierras, el principal del pueblo de Pimachi responde con mayor precisión sobre las dos etnias:

“... dixo que lo que saue /Fol.7/ y a oido decir a sus antepasados es que los dichos indios llaguases fue de nación que bibio siempre en las punas y los guaris fueron de nacion gigantes barbados los quales crio el sol y a los llaguases el rayo con cuya caussa y que estos guaris les pircaron las patas de las chacaras y hizieron las azequias y las (......) y unos destos tenian dos caras una atras y otra delante que se llamaban Gurris ascayes y estos comian gente muchachos yndios y los Llaguases se aparecian y eran invisibles y andaban por debajo de la tierra...."

En la memoria colectiva de mediados del siglo XVII, expresada por sus representantes, estaba definida muy claramente la composición étnica de los habitantes de Cajatambo. Domingo Rimachi y otros principales explican con lujo de detalles sobre los llacuaces y huaris como sus antecesores, de sus orígenes, las divinidades a las que adoraban y los ritos que se practicaban en torno a estos símbolos religiosos andinos en pleno ejercicio. De los llaguaces, dice el principal de Pimachi, que "fue una nación que vivió siempre en las punas"; es decir, eran una nación de cazadores y pastores de camélidos sudamericanos que vivían en las estepas de altura que se abren tanto hacia el lado oriental como al lado occidental de la cordillera de los Andes. La meseta de Junín y la Pampa de Lampas, eran para ellos las planicies más amplias para el pastoreo de camélidos sudamericanos. Sobre los guaris agrega este yachaj, que “... los guaris fueron de nación gigantes barbados...” La referencia espacial o geográfica de la procedencia de los guaris es el Titicaca, es decir, la gran meseta del Collao peruano-boliviano. La referencia de gigantes barbados atribuido a los guaris, hacía referencia sobre la estatura mayor de los guaris con respecto a los llacuaces y lo de barbados da la idea de que los antecesores guaris no eran lampiños, llevaban barbas a diferencia de los llaguaces que no las tenían.

De los dioses principales de estas dos naciones declara Domingo Rimachi, que los guaris eran criaturas del dios sol (inti) y que los llaguaces eran hijos del dios rayo (libiac o lliuyaj), dos naciones de procedencia distinta y adoradores de dioses también distintos. Otros declarantes precisarán los rituales de cada una de las divinidades, pero Rimachi da cuenta en pocas palabras el rasgo cultural más importante de los guaris en la región. Declara que “... estos guaris les pircaron las patas de las chacaras y hicieron las azequias y las..." Por esta breve referencia entendemos que fueron los guaris quienes desarrollaron la ingeniería agrícola de riego en esta zona de sus dominios, con dos técnicas básicas de dominio a la naturaleza agreste del suelo andino: la andenería y la agricultura de riego, con la construcción de canales y reservorios artificiales. "Pircaron la pata de las chácaras", nos lleva a entender que desarrollaron el sistema de terraplenes en base a pircas de piedra para ganar espacio para la agricultura en zonas muy empinadas como son las laderas del lado occidental de los Andes. En otros términos, hicieron paterías (patas) o andenerías de las chácaras en su equivalente en castellano. Además de este gran avance de la ingeniería agrícola, construyeron las acequias o canales de riego, probablemente complementado con los reservorios de agua, que en el documento no aparece explicado sino como “...las azequias y las...." Con estos datos, Domingo Rimachi nos está diciendo que los guaris trajeron e impusieron en esta región la agricultura de riego, con canales y reservorios hechos desde largas distancias y ampliaron la frontera agrícola hasta los lugares más difíciles donde construyeron andenes para ganar terreno. Sobre una agricultura incipiente basada en las precipitaciones de lluvia y rudimentos del riego, que hoy se conoce como agricultura de secano o agricultura temporaria, que desarrollaron los chavín, los guaris fueron mucho más allá en la invención o aplicación del método hidráulico y de terraplenes en la agricultura de la región Cajatambo, antes de la conquista de los incas. 
Las declaraciones del testigo Andrés Chaupis Yauri, fiscal del pueblo de Otuco, por aquel tiempo anexo de la doctrina de San Pedro de Acas, son más extensas y de mayor detalle que del testigo de Pimachi. Otuco o Utuc (como lo designan en la actualidad) era un ayllu ubicado en la falda del cerro cercano a Raján Viejo, situado en región suni, a unos tres kilómetros arriba del actual pueblo de Huanri y a unos quince kilómetros de Pimachi, situado en una pequeña cuenca al oeste de Huanri. Otuco era una agrupación social huari, que vivía a base de la agricultura de secano y complementaba su economía con los productos de zona quichua de Huanri, cultivaban especialmente tubérculos: papa, oca, mashua. Huanri, por su ubicación en zona quichua baja era el principal productor de maíz. En la causa seguida por el visitador Bernardo de Noboa el 25 de julio de 1656, Andrés Chaupis Yauri, el más destacado conocedor de la historia regional de Cajatambo se explaya con mucha solvencia y sabiduría frente al visitador. Por sus versiones tenemos información acerca de los héroes fundadores de la región y del dios principal: el Apu Libiac Cancharco. Esta es su versión:

“... sus malquis que eran sus mayores ydolos que tenian para quien hacian chacaras y tenian colcas las ofrendas eran para los malquis siguientes el Saramama del ydolo comun y otros ydolos que tenian diziendo (.......) y la historia destos malquis es la siguiente que a lo que se acuerda y a oido desir a sus pasados que el Apu Libiac Cancharco cayo del cielo a modo de rayo y este tubo muchos hijos y unos enbio por unas partes y otros por otras como fue Libiac Choquerunto Libiac Carua Runtuy los primeros progenitores del aillo Chaupis Osirac Otuc y Libiac Raupoma y Vichupoma del aillo Xulca y Libiac Nauin Tupia y a Libiac Guac Tupiac del aillo Allauca todos conquistadores llacuazes a los quales quando los enbio el apo su padre les dio un poco de tierra que llebassen para conquistar tierras donde bibiessen. El qual les dixo que en hallando tierra semejante a la que llebaban alli se quedasen porque alli tendrian sus comidas y bebidas y hasiendas y habiendo llegado a Mangas los yndios del dho pueblo no los quisieron recevir con que pasaron al pueblo de Guancos los quales los recibieron con agasajo y se estuvieron un año con ellos y aviendo cotejado la dicha tierra y visto que no venian con la del dicho pueblo de Guancos passaron a este dicho pueblo de Otuco y estando arriba del enbiaron a un muchacho con una llama y los yndios que actualmente bibian en este dho pueblo en sus chacaras y le llamaban el aillo Guari Guachancho y el aillo Taruca Chancho los quales le enbiaron a pedir alguna milcapa y comida y los /Fol.11v./dichos yndios mataron al dicho muchacho y la llama viva le quitaron el pellejo desta manera se la bolvieron a despachar a los susodichos los quales viendolo se bajaron donde estaban los del aillo dicho y hallandolos baylando el Guari Libiac con tambores y pincollos enbiaron a un yndio primero convertido en un pajarillo que llaman chuichu el qual venia cantando chuich y los del aillo Guari Guachicho dixeron que quien eran aquellos llaguases que tenian muy pocas tulmas pues enbiaban aquel chuichu y los susodhos como corridos armaron una tempestad de neblinas espesass negras y gran graniço como guegos grandes y enbistieron con rives de oro y de plata Chaupis Guaras y con suintas que son rives grandes mataron a todos los yndios que abia en dichos aillos dueños de dicho pueblo con que los conquistaron y quitaron cassas chacaras y haçienda y comidas y solo dejaron uno bibo porque se les humillo llamado Marca Cuipac y a su hermano Paria Putacac y por esta caussa y ser los primeros conquistadores los tenian en tres bobedas muy curiosas debajo de la tierra arriba en los pueblos biejos llamados Marca Putacum enterrados en ellas y toda su familia en la bobeda o machay Choqueruntu y su hermano Carua Runtuc estaba en otro con su familia donde abia setenta y cinco cabezas de dho aillo Conde Ricuy y en el aillo Chaupis Otuco y el de Xulca estaba Libiac Raupoma Uchupoma y su familia que eran cuarenta y dos cabezas y en el del aillo Allauca esta Libiac Rum Tupia con su hermano Libiac Cuauac Tupia con cuarenta y cuatro cabezas de su familia que 
enseño y se quemaron al presente por el dho Sr vissor (visitador)....." (Versión de la visita a Otuco transcrita por Pierre Duviols, 1986: 52-53).

En este amplio párrafo hay mucha información valiosa para entender a los héroes fundadores, a las divinidades mayores y menores de las dos etnias y los rituales instituidos en honor a ellos, a las huacas y a los camaquenes. Aparecen también los sacerdotes principales y secundarios, las sacerdotizas encargadas del culto y los papeles que asumían estas jerarquías religiosas andinas aún después de largos procesos de catequización cristiana. Nos interesa la versión sobre la deidad principal y los héroes fundadores de los pueblos del alto Pativilca.

Por la memoria de Andrés Chaupis tenemos la versión de que el Apu Libiac Cancharco aparece en ese mundo desde el firmamento, como todos los dioses, explicados por otras sociedades en circunstancias distintas. "Cayó del cielo a modo de rayo", dice el informante refiriéndose al padre fundador. Luego, no da mayores referencias de la vida y hechos de Libiac Cancharco. Queda como el dios padre, el símbolo procreador de los verdaderos fundadores, sus hijos, cuyos restos se mantienen en los machayes convertidos en mallquis y camaquenes ${ }^{22}$. Estos camaquenes recibían hasta entonces, homenajes y cultos colectivos especiales, a cargo de los sacerdotes andinos, a quienes los españoles les llaman "hechiceros", “dogmatizadores" y otros adjetivos despectivos y hasta demoniacos. En Otuco y en las otras poblaciones de la zona estas deidades tenían chacras dedicadas al cultivo de productos para el culto, especialmente del maíz; también tenían colcas especiales (depósitos) para guardar los alimentos y productos dedicados al culto a los camaquenes. Es decir, los pueblos de origen huari del Cajatambo del siglo XVII, mantenían muy bien organizado los cultos a sus divinidades, con ceremonias especiales oficiadas por los sacerdotes, con músicas y bailes, con ayunos, con comidas y bebidas y con amplia participación de hombres y mujeres que habitaban en esas poblaciones.

Los verdaderos héroes fundadores o "conquistadores" de esas poblaciones vienen a ser, según el yachaj Andrés Chaupis, los hijos del Apo Libiac Cancharco. Chaupis dice que Libiac Cancharco "tubo muchos hijos", pero los que reciben el mandato de fundar pueblos en esta región son sólo tres parejas, que fundaron pueblos con nombres propios. Se puede entender que los muchos hijos incluye a los tres hijos de Yanaramán que aparecen en el mito contado por Marcapari en Cauri: Raria Paucar, Callupa y Nabpara, que son héroes fundadores del lado oriental del Huayhuash. A la orden del progenitor, a "unos enbio unas partes y otros por otras", los héroes fundadores de los llacuaces aparecen como los antepasados de las localidades en el siguiente orden:

\section{Hijos de Libiac Cancharco}

Libiac Choquerunto y Libiac Carhua Runtuy

Libiac Raupoma y Vichupoma

Libiac Nauin Tupia y Libiac Cuac Tupiac

\section{Ayllus fundados}

Chaupis, Osirac y Otuc

Xulca

Allauca

Las parejas de fundadores no fueron enviados por su padre expresamente a determinados lugares. Tenían que apearse allí donde la tierra era buena para cultivarla y tener un buen porvenir con los frutos que da la tierra. Con este fin, dice el informante, "el apo su padre les dio un poco de tierra que llebassen para conquistar tierras donde bibiessen". Por estos datos en que aparecde el símbolo de la tierra fértil, hay confusión de si el dios Apo Libiac Cancharco fue el padre de los llaguaces cazadores y pastores de la puna o de los guaris

22 Los mallquis eran los restos óseos de los héroes fundadores y los camaquenes sus espíritus. Los mallquis embalsamados se guardaban en los machayes (cuevas) y eran objeto de cultos especiales. 
agricultores de las tierras bajas. Pero en la memoria de Andrés Chaupis la historia mítica sigue su curso. Las tres parejas aparecen juntas visitando varios lugares cotejando la tierra que llevan consigo y la tierra del lugar donde se apean, tal como habían sido instruidos: "hallando tierra semejante a la que llebaban alli se quedassen porque alli tendrían comidas y bebidas y haciendas". Este mandato del dios padre Apo Libiac Cancharco, no es propiamente la simbolización de héroes fundadores de pueblos o grupos sociales, sino de héroes conquistadores de pueblos sedentarios, los guaris, que vivían del cultivo de la tierra en zonas intermedias del alto Pativilca, a lo que Duviols (1973) ha denominado "lucha por la complementariedad en una estructura dual de oposiciones". En efecto, los buscadores de tierras buenas reciben distintas respuestas en su peregrinaje por las faldas occidentales de la cordillera de Huayhuash.

En primer lugar llegan al pueblo de Mangas, situado en una de las crestas del lado oeste de la pacarina del Yerupajá, en el lado izquierdo del río Pativilca. En este primer contacto con los guaris, los enviados de Libiac Carcharco no tuvieron suerte: "los yndios del dho pueblo no los quisieron recebir", por lo que continuaron viajando para llegar al pueblo de Guancos, donde tuvieron mejor suerte porque "los recibieron con agasajo". En este segundo pueblo de agricultores se quedarían todo un año gozando de la hospitalidad de su gente. Pero no se quedaron a vivir allí, porque cotejando la tierra del pueblo de Guancos con la que llevaban no eran compatibles, continuaron su camino para llegar finalmente "a este dicho pueblo de Otuco", que está al otro lado del río Pativilca, en uno de los flancos de la cordillera negra. Entre Mangas y Otuco no sólo hay una separación del río Pativilca que discurre por la profundidad de dos grandes cerros donde se ubican varias poblaciones y que en este tramo se denomina río $\mathrm{Negro}^{23}$ sino que la distancia es considerable, de unos $30 \mathrm{~km}$. Guancos debió estar en la parte intermedia entre Mangas y Otuco, es decir entre los pueblos actuales de Gorgorillo, Llaclla, Canis y Cajamarquilla. No existe pueblo o vestigios arqueológicos conocido con este nombre, por lo que suponemos que la ubicación de Guancos debió estar situada entre los lugares citados.

La condición de conquistadores sanguinarios y de rapiña de los héroes fundadores llacuaces sale a relucir en el contacto con los de Otuco. Según el relato de Chaupis, los hijos de Libiac Cancharco no entran directamente a este pueblo, lo hacen empleando una estratagema a través de un intermediario, un muchacho, con lo que la comitiva aumenta a más de las tres parejas. Dice don Andrés "estando arriba del (del pueblo de Otuco) enviaron a un muchacho con una llama.... para pedir alguna milcapa y comida". La respuesta de los ayllus de Guari Guachancho y de Taruca Chancho residentes en las inmediaciones de Otuco es violenta y hostil: "dichos yndios mataron al dicho muchacho y (a) la llama viva le quitaron el pellejo desta manera se la bolvieron a despachar”. Los llacuaces dolidos por la afrenta utilizaron todavía otro recurso más enviando a un yndio convertido en un pájaro llamado chuichu que entró cantando ante los yndios del ayllo Guari Guachancho quienes se encontraban de fiesta bailando con música de tambores y pincullos. Los guaris al ver al chuichu (Probablemente el huaychó) lo menospreciaron y lo calificaron como un acto de cobardía y de mal gusto propio de los llacuaces de las alturas. Como consecuencia de esta segunda afrenta y menosprecio, los llacuaces conquistadores entran violentamente a Otuco: "armaron una tempestad de neblinas espesas negras y gran graniço como guagos grandes y embistieron con rives de oro y plata.....mataron a todos los yndios que había en dichos ayllos". En resumen, arrasaron con todo el pueblo, "los conquistaron y quitaron sus cassas chacaras y haçienda y comidas". No sólo dieron muerte a todos los guaris sino que

23 Desde las tierras negras que caen de Shushún cerca de Tauripón las aguas se tiñen de negro y su caudal continúa oscuro hasta su desembocadura en el mar Pacífico, por lo que los lugareños lo conocen como río Negro. 
se apoderaron de todo y se quedaron como los nuevos dueños del pueblo, de sus bienes y de sus tierras. Dejaron vivo sólo a dos guaris "porque se les humillo". Estos sobrevivientes se llamaban Marca Cuipac y su hermano Marca Putacum, con quienes formarían una alianza llacuaz-guari en la localidad de Otuco. La violenta irrupción de los llacuaces en tierras de los guaris y su respuesta despectiva y afrentosa están muy bien simbolizados en este relato del sabio Chaupis Yauri, pero hay que entender que éste, probablemente largo proceso de luchas étnicas, concluye inevitablemente en una fusión social y cultural, de la que se ocupa precisamente Pierre Duviols en su primer trabajo sobre esta parte del antiguo Cajatambo.

Los restos mortales de estos personajes míticos, héroes conquistadores y fundadores de una cultura mixta (guari-llacuaz), seguían siendo venerados hasta los tiempos de la visita de Bernardo de Noboa, bajo de denominación de mallquis, símbolos presentes de los primeros progenitores de esta nueva cultura regional. "Por ser los primeros conquistadores los tenían en tres bobedas curiosas .... arriba en los pueblos biejos llamados Marca Putacam...", dice Chaupis. Probablemente, estas tres bóvedas eran construcciones de piedra y barro debajo de cuevas naturales donde depositaban a los cadáveres de los difuntos, como los hay hasta ahora en distintos pueblos de la región. Eran los cementerios prehispánicos, que los incas continuaron practicándolo para enterrar a sus muertos. Por ser dignatarios de la primera generación de llacuaces estaban enterrados en "bobedas curiosas", es decir bóvedas muy bien hechas, enlucidas con barro por la parte exterior y con una ventanilla por donde se les sacaba cada vez que había que rendirles culto, con fiestas, bailes, comidas y bebidas. A qué pueblo llamado Marca Putacam se refiere Chaupis en este relato? En las partes altas de las ruinas de Utuc no hay vestigios de población antigua, con excepción del antiguo pueblo conocido como Raján Viejo, situado a unos dos kilómetros y no más de cien metros de altitud con respecto de Utuc. Lo más probable es que Marca Putacam o parte de ella eran las cuevas que se forman de la colosal roca que los campesinos llaman hoy Parinajrumi (Piedra que está por volar). Esta gigantesca piedra semicircular y alargada, considerada lugar sagrado hasta nuestros días, de unos cuarenta metros de altura, está suspendida sobre otras rocas y da la impresión que está por precipitarse sobre el cerro de fuerte pendiente que da hacia la toma del canal de Rauyanca en el pueblo maicero de Huanri, tres kilómetros cuesta abajo. En estos machayes con bóvedas muy curiosas estaban enterrados los cadáveres de toda la familia de los progenitores de esta etnia, según la información de Andrés Chaupis.

En una de las cuevas estaban los cuerpos de Choqueruntu y de su hermano (o hermana o esposa) Carua Runtu, con toda su familia, como menciona don Andrés. Cada cabeza de progenitores tenía su propia bóveda y estaba acompañado de un considerable número de sus descendientes. Choqueruntu y Caruaruntu estaban en medio de setenticinco (75) cadáveres de los suyos, pertenecientes al ayllo de Conde Ricuy. En la segunda bóveda estaban Libiac Raupoma y Libiac Uchupoma, con otros cuarentidos (42) cadáveres de sus progenitores, pertenecientes a los ayllos de Chaupis Otuco y Xulca. En la tercera bóveda estaban los cadáveres de Libiac Rum Tupia y la de su hermano (o hermana) Libiac Cuauac Tupia, con otros cuarenticuatro (44) miembros de su familia, pertenecientes al ayllo de Allauca. Andrés Chaupis recuerda con mucha precisión la disposición de las bóvedas familiares de los conquistadores hijos de Apo Libiac Cancharco, porque durante las festividades del calendario agrícola de Otuco estos mallquis eran sacados de los machayes y conducidos al pueblo. Concluidas las ceremonias y cultos eran igualmente devueltos a los machayes donde estaban las bóvedas de los héroes fundadores. La distribución de los pares de conquistadores y sus correspondiente ayllos precisados por el mismo informante coinciden parcialmente en la disposición de las bóvedas del cementerio llacuaz. Bien es verdad, que la escritura de los nombres de los progenitores y el nombre de los ayllos no 
siempre coinciden en el documento, aparecen distintas maneras de citar nombres y lugares, que probablemente son errores de precisión de los traductores y de los escribientes. Lo más probable es que el escribiente no haya consignado correctamente estos nombres, ya sea por incorrecta traducción de la declaración del Fiscal de Otuco por parte del intérprete o por error y confusión de nombre y lugares del escribiente que registraba lo que declaraban los procesados. En la memoria de Chaupis estaban muy claros los datos de sus antepasados, él era uno de los líderes de prestigio y de amplia sapiencia del pueblo de Otuco y como tal conocía al detalle la historia oral de su pueblo y de la genealogía de su estirpe, desde antes de la conquista de la región por los incas y luego por los españoles.

\section{Origen mítico de los alimentos andinos}

\section{El mito de la Mama Rayguana}

Otra variedad de mitos explican el origen de los productos alimenticios del hombre andino. Sobre esta racionalidad originaria de lo que comen para subsistir, hay también varios mitos que los cronistas y los documentos administrativos coloniales consignaron en sus escritos. El mito de la Mama Rayguana, uno de los más importantes relatos de este género, tiene que ver con el origen de la papa y de otros productos alimenticios del mundo andino. Iniciamos esta sección con la versión dada en San Pedro de Hacas, una de las doctrinas del antiguo Cajatambo, donde los principales convocados en la causa de idolatrías dan valiosas informaciones sobre esta deidad andina. Son precisamente las declaraciones que dan los procesados en el pueblo de Hacas los que proporcionan las más variadas versiones de la mitología prehispánica del antiguo Cajatambo.

La versión de Hernando Hacas Poma, sacerdote principal del ayllo de Chacas, en el pueblo de San Pedro de Hacas (Acas actual) es particularmente importante. Don Hernando dijo tener 80 años de edad, en su declaración del 20 de enero de 1657, ante el visitador eclesiástico de idolatrías Bernardo de Noboa, por lo que se calcula que nació durante el virreinato de Francisco de Toledo (1577?) y asumió la responsabilidad de ser sacerdote mayor de la religión andina a los cuarenta años, es decir aproximadamente en 1617, por sus dotes de líder, organizador y magnífico orador, así como por poseer una extraordinaria memoria para relatar la historia social de su pueblo. Ante los visitadores ofrece interesantes datos acerca de la Mama Rayguana, madre de la papa y de toda la ideología religiosa en ejercicio de la que era cabeza más visible. A la pregunta de si sabe acerca de los ritos idolátricos en esta localidad, declara:

“... que quando barbechan sus chacras que es por el tiempo que se alsan las aguas
por resurrección coxen un pajaro que llaman yucyuc y lo ponen en unas andas y con
dansas de yndios pallas y gran borrachera de chicha le bailan y hacen gran fiesta y
le hacen ofrendas al dicho pajaro porque tienen tradision que este dicho pajaro trajo
las conopas de las comidas papas ocas del pueblo de Caima y se los quito a la mujer
Rayguana con fabulas que para esto quentan de sus antiguallas...." (Expediente $\mathrm{N}^{\circ}$
XI del legajo 6 del Archivo Arzobispal de Lima).

Un ave que en la zona andina llaman yucyuc (tordo andino o zorzal: tordus musicus o plilomelus) aparece en Acas sacralizado, porque el mito refiere que fue él quien trajo las comidas de Caima, una localidad situada al otro lado de la cordillera, en Huánuco. El yucyuc viene a ser el héroe que trajo las conopas ${ }^{24}$ de tubérculos: papas, ocas y probablemente la mashua, que no menciona el informante. Se los hurtó a Rayguana, una mujer diosa que tenía en custodia a todas las conopas de las plantas comestibles, domesticadas en tierras andinas.

24 Conopas o espíritus reproductores de las plantas domesticadas. 
Este informante no menciona cómo se ingenió el yucyuc para traer las conopas controladas por la diosa, de la que se encargará de explicar otro informante. Pero todos coinciden que fue el yucyuc el artífice de esta hazaña, sin la cual no habría comidas en Hacas, por lo que tampoco habría habitantes. En cambio, don Hernando relata los rituales dedicados al yucyuc en su pueblo, en el que él era el yachaj principal. Cuenta que en la época en "...que se alsan las aguas por resurrección", del barbecho de las sementeras de diciembre y enero o talvez coincidente con la semana santa que termina con la pascua de resurrección; es decir, en marzo o abril, cuando las lluvias han aumentado las aguas para el riego, rinden culto al benefactor yucyuc. Cogen al pájaro del campo y lo pasean en andas con gran regocijo, con música, bailes y acompañamiento de pallas que cantan, toman abundante chicha en señal de alegría por el crecimiento de las sementeras traídas por el yucyuc.

El ritual festivo dedicado a esta ave en Acas es de gran interés, porque el yucyuc o zorzal es un plumífero abundante en el mundo entero y se caracteriza por vivir debajo de bosques y alimentarse de lombrices y bichos rastreros. El yucyuc del antiguo Cajatambo es más conocido como yuquish, es del tamaño de una paloma cuculí, de color pardo oscuro, de pico y patas de color amarillo, camina en los campos barbechados en busca de lombrices dando saltitos con los pies juntos. En la actualidad el yuquish en las provincias de Bolognesi y Ocros es un ave más o menos respetado por la gente, a nadie se le ocurre agredirlo, molestarlo o matarlo. Su carne no es culturalmente consumible, por lo que aparece como una ave inofensiva. Hay un leve sentimiento de rencor inconsciente de la gente, pero también un aprecio. El aparente rencor viene por otro mito que sigue trasmitiéndose en los pueblos de la región del antiguo Cajatambo, en el que el yucyuc es también personaje principal:

"Una vez, el yuquish (yucyuc) fue llamado por dios al cielo y él obedeció el llamado $y$ voló al cielo. Dios le encargó al yuquish que llevara a la tierra un grano de oro para entregarlo a los hombres y se los pusieran como dientes para masticar bien los alimentos. Le encargó también que les dijera a los hombres que para vivir sin contratiempos comieran una vez cada tres días, a fin de que no sufran en busca de alimentos. El zorzal bajó a la tierra con los dos encargos, pero en el camino de regreso se le ocurrió ponerse el diente de oro en el pico y las patas, le pareció que le quedaba muy hermoso por el brillo dorado. Se quedó con el oro en el pico y las patas y entregó a los hombres en la tierra un grano de maíz blanco, diciéndole que por encargo de dios se lo pusieran como dientes y que además comieran tres veces al día. Por esta razón, los yuquises tienen el pico y las patas doradas y los hombres dientes blancos que se enferman de caries y lo peor, tienen que trabajar duro par comer tres veces al día. Cuando dios se enteró que el yuquish no había cumplido con los encargos que le encomendó, lo llamó nuevamente para castigarle: le prohibió en adelante comer granos y frutos de la tierra, se alimentaría sólo de los bichos que viven debajo de la tierra, asimismo le maniató los pies, para que en adelante caminara saltando con las dos patas, como si estuvieran engrilletados." (Relato de doña Ambrosia Guimaray, recogido en Santiago de Chilcas, Ancash).

Por el mensaje de este mito, la gente que tiene conocimiento del embuste cometido por el yuquish lo desprecia, al mismo tiempo que lo respeta. Con más razón, cuando sufre el dolor de las muelas, que de haber sido de oro no se cariarían, y cuando tienen que trabajar de sol a sol cultivando la tierra para comer tres veces al día. Pero también lo aprecian y lo admiran por su hermoso canto de la mañana y de la tarde. El yuquish es un ave canora y su canto avisa al campesino la hora de ir a trabajar y la hora de descansar: seis de la mañana y seis de la tarde aproximadamente. Los campesinos, cuando trabajan la tierra durante los días de lluvia y las nubes no dejan pasar los rayos del sol, esperan el canto del zorzal para irse a casa. Cuando el ave comienza a cantar, culmina el trabajo y se retiran a descansar, porque saben que ya se acerca la noche. Para la gente del campo, el zorzal no se equivoca 
en anunciar el tiempo de comenzar y terminar las labores. Su canto es una letanía, que se repite por un buen rato, por la tarde, hasta que caiga la noche. Según los campesinos, el yuquish se lamenta todos los días de su mala suerte familiar, cuando dice en quechua: ¡Puyii, puyii; por dios! / ¡tíya, naná: chichu!/ ¡mac'a, tac'a: pior, pior, pior! ${ }^{25}$

¡Puyii, puyii; por dios!

¡Mi tía, mi hermana, encinta!

¡Le pego, le chanco:

peor, peor, peor!

Otra versión sobre el tema de la Mama Rayguana corresponde al procesado Hernando Chaupis Condor, sacerdote andino del ayllo de Anarqui (o de Yanaqui), también de San Pedro de Hacas, de 70 años de edad, que el 23 de enero de 1657 declaró ante el visitador de idolatrías Bernardo de Noboa. Este sacerdote era segundo en la jerarquía en el pueblo de Acas y se explaya con mayor amplitud y precisión sobre el mito de la madre de la papa. Chaupis Condor proporciona el relato completo sobre el mito de la Mama Raiguana y relata con detalles la condición de conservadora de las conopas de las comidas que consumen de la diosa de Caina:

“... que quando barbechan las chacras para sembrarlas otro año cojen un pajaro que llaman yucyuc el qual tiene los pies y pico amarillo y lo ponen en unas andas con flores y le ponen camiseta y manta que le hasen al proposito y solamente se le parese la cabessa y en los patios de sus colcas que llaman de comunidad y de sus malquis queman delante de dicho pajaro coca sebo cuyes chicha y polvos de coricallanca por modo de ynsienso y hecho este sachrificio sacan en prosesion al dicho pájaro por las calles con pallas y tamborcillos cantandole en su lengua los conopas de las comidas de Caina y se lo quitaste a la madre Rayguana y acabada la prosesión sueltan al dicho pájaro y beben y baylan y se emborrachan mucho más que en otros sachrificios porque tienen tradisión de sus antiguos y la observan oi y disen que el dicho pajaro yucyuc rogo al pajarillo sacracha que en español se llama papamosca llebase un puñado de pulgas y se las echase en los ojos de la madre Rayguana que estaba en el pueblo de Caina y mientras se rascaba la picadura de las pulgas soltaría al hijo conopa que tenia en sus brasos y entonces el pajaro yucyuc se lo hurtaria y habiendole el dicho pajaro sacrachi (sic) echandole las pulgas solto el hijo y entonces bajo un aguila y le arrebato y le rogo la madre Rayguana no se llavase su hijuelo que ella repartiria todas las comidas y assi repartio a los yndios serranos papas ocas olluco masuas quinua y a los yndios yungas mais yucas camote frisoles y por esta caussa adoran a la madre Rayguana como a diosa y criadora de las comidas y al pajaro yucyuc como a caussa istrumental y por quien la madre Rayguana repartio comida..." (Expediente $\mathrm{N}^{\circ} \mathrm{XI}$ del legajo 6 del Archivo Arzobispal de Lima).

El ritual colectivo al yucyuc contado por Hernando Chaupis Cóndor es similar a lo contado por Hernando Hacas Poma, pero con mayor detalle. Este testigo precisa el modo cómo realizan todo el ritual a esta ave en Hacas, cómo lo visten, de tal suerte que del ave sólo se le ve la cabeza; que le ofrecen un pagapo (pago), consistente en quemar "coca, sebo, cuyes chicha y polvos"; que este polvo es traído del famoso lugar "de coricallanca", producto que da humo a manera de incienso, que probablemente es una madera que produce humo aromático. Al pasearlo en procesión por las calles de Acas, le cantan colectivamente mencionando su hazaña de haber traído las conopas de las comidas de Caina y luego lo sueltan para que vuele al campo donde vive con los suyos. Declara también que es el

25 Augusto Cardich (1981) recoge también esta versión del canto del yuc yuc en Huánuco, por lo que se estima que el canto relojero del zorzal abarca toda la región centro andina. César Ángeles Caballero (1988) reproduce el mismo canto del zorzal en el quechua del Callejón de Huaylas. 
más grande homenaje (sacrificio) que le tributan al yucyuc en agradecimiento a su acción benefactora para la vida de los hombres: “...beben y baylan y se emborrachan mucho más que en otros sachrificios porque tienen tradision de sus antiguos.." Por la versión de este mito, el zorzal era para ellos un ave sacralizada, la historia de su vida estaba íntimamente ligada a la vida feliz de los hombres, que por su astucia y su heroísmo, tienen papas, olluco, oca, mashua, quinua, para cultivar en la tierra y comer de ellas. Por eso lo veneraban en el tiempo que visita Noboa y que hoy han perdido esa memoria mítica pero que está en el subconciente colectivo, por lo que lo respetan y no lo ofenden en ningún caso.

En el relato de Chaupis está suficientemente explicado el modo cómo el yucyuc le roba los conopas a la Mama Rayguana. Para lograr su osada aventura, el yucyuc solicita la colaboración de una pequeña ave conocida como sacracha que en castellano llamaban papamosca (Probablemente el colibrí o picaflor). Con este aliado tejen un ardid que da buenos resultados. El plan consistía en que la sacracha, ave pequeña y sumamente ágil le echase un puñado de pulgas en los ojos, a fin de que la Mama Rayguana, desesperada por las picaduras de las pulgas, soltase al conopa que llevaba en los brazos. Así fue en efecto, las pulgas cumplieron su papel picándole a la madre de las comidas y efectivamente desatendió a la conopa bajo su cuidado. No fue el yucyuc quien se apoderó de la conopa desguarnecida, fue, según Chaupis, "un aguila y le arrebató" el hijo o sea al conopa que la había descuidado por un solo momento. Desesperada la Mama Rayguana, al ver que el águila se llevaba "a su hijuelo" por los aires, le rogó para que no se llevara y que en compensación "repartiría todas las comidas", como que así lo hizo. La consecuencia de este ardid tejido por el yucyuc, en la que intervienen la sacracha y el águila, es de lo más beneficioso para los habitantes de esta tierra andina. Mama Rayguana, la madre criadora de todas las conopas de las comidas existentes, repartió alimentos a los pueblos serranos y a los yungas. A los de la sierra les repartió sin condiciones: papa, ollucos, oca, mashua, quinua y a los de la costa les tocó: maíz, yuca, camote, frijoles. Había en los pueblos del antiguo Cajatambo suficientes razones para que la Mama Rayguana y el yucyuc fueran sacralizados por los agricultores andinos de esta región; ella era la madre de todos esos alimentos. Su asiento era Caina, pueblo situado en el lado oriental de la cordillera Huayhuash, en Huánuco. El yucyuc recibía estos sacrificios y homenajes de adoración, porque fue gracias a la estrategia de él que Mama Rayguana repartió los alimentos.

Hay más información sobre este relato mítico. Otro informante que ofrece datos de gran valor sobre los rituales religiosos prehispánicos es don Christobal Pampacondor, también sacerdote de San Pedro de Hacas, natural del ayllo de Chaca, de 68 años de edad, quien declara ante en visitador eclesiástico Bernardo de Noboa el 28 de enero de 1657. Da importantes informaciones acerca de la Mama Rayguana. Pampacondor no sólo da la versión de lo que sabe, ha oído decir y ha visto, como declara la mayoría de los encausados, él relata su participación personal en estos eventos festivos en honor al yucyuc:

“... y quando quieren barbechar sus chacras para sembrar coxen un pajaro que llaman yucyuc y delante del queman cuyes coca sebo y chicha y este testigo lo a echo y llevado dicho pajaro en las manos baylando y pallas con tamborcillos y luego beben y baylan y hasen esta fiesta al dicho pájaro y lo mochan porque disen les trajo del pueblo Caina y le quito a la mujer Rayguana un hijo conopa que tenia en los brassos que criaba todas las comidas papa mais ocas y por haberse traido el dicho conopa a estos pueblos de Hacas tienen todas las comidas por cuya caussa se hacen fiesta y adorasion..." (Expediente $\mathrm{N}^{\circ}$ XI del legajo 6 del Archivo Arzobispal de Lima).

Pampacóndor relata el escenario del culto al yucyuc en su pueblo en los mismos términos que los otros informantes y repite escuetamente la hazaña del yucyuc para hurtar al conopa 
de los brazos de la Mama Rayguana en el pueblo de Caina. Lo importante y nuevo de la versión es que declara que él ha sido uno de los participantes de estas ceremonias dedicadas al yucyuc: "(él) lo a echo y llevado dicho pajaro en las manos baylando". Probablemente, participó en coger al yucyuc para las ceremonias o era el encargado de pasearlo por las calles cogido de las manos, bailando con el acompañamiento de las pallas cantoras y el toque de los tamborcillos, que en estos casos era el instrumento musical que daba el ritmo del baile, antes de colocarlo en las andas y pasearlo en procesión. Los demás datos que da son similares a los de sus paisanos, indicando que las comidas vinieron de Caina donde la Mama Rayguana cuidaba y protegía en sus brazos a los conopas de las comidas y que por eso en su pueblo de Hacas (Acas) "tienen todas las comidas". Igualmente justifica la sacralización de Mama Rayguana y del yucyuc y de las ceremonias que se ofrecen en su honor. En Acas, como ya hemos mencionado en líneas anteriores, cultivan hasta hoy las mejores variedades de papa de toda la región, pero ya no lo recuerdan a la diosa Rayguana ni a la hazaña del zorzal. Pero siguen cultivando varias especies de papa nativa, incluida la variedad de papa conocida como rayhuana, tubérculo arenoso y de pulpa rosada-blanca. No adoran más al zorzal, pero lo siguen respetando como un ave inofensiva, cuya carne no se come. Tampoco el zorzal es temeroso ante los hombres, como otras aves, se pasea en los campos barbechados, dando saltos a dos pies en busca de bichos del subsuelo.

Una versión más de la mitología sobre los alimentos, esta vez acerca del maíz. Corresponde al testigo Pedro Sarmiento, también sacerdote secundario del pueblo de San Pedo de Hacas, del ayllu de Yanaque, 64 años de edad, quien declara ante el visitador Noboa, el 28 de enero de 1657 lo siguiente:

“... quando coxen todas sus chacras y sementeras recogen las masorcas que llaman airiguas y misa sara y mama sara y del las hasen un ramillete en un palo de maguei con ramos de molle y lo lleba en la mano un yndio moseton en un sitio donde esta el ydolo Tauris se juntan todos los del pueblo y las viejas con tamborcillos baylan todos el bayle supersticioso de la airigua y hasen esta fiesta a sus malquis e ydolos porque le a dado mais y comidas y beben toda la noche hasta que se emborrachan y despues de echa esta fiesta los dichos ministros de ydolos parte de aquellas masorcas del dicho ramillete las hasen chicha y parte dellas con la dicha chicha ofresen y queman en sachrifisio..." (Expediente $\mathrm{N}^{\circ} \mathrm{XI}$ del legajo 6 del Archivo Arzobispal de Lima).

En este caso, el declarante Pedro Sarmiento habla acerca de los rituales de la cosecha de maíz en Acas, donde la "misa sara" y "mama sara" que extraen de la misma cosecha es motivo de ceremonias especiales. No da información qué es y como se le reconoce a la misa sara y mama sara, se dedica a relatar lo que una vez cogidas estas mazorcas forman un "ramillete" y lo amarran en un palo de maguey adornado con ramas de molle y lo pasean por intermedio de un indio "moseton" y van hacia el adoratorio del ídolo Tauris. Este ritual es acompañado por toda la gente del pueblo, donde las mujeres de edad van cantando y bailando al son de tamborcillos la canción ritual de la airigua. El ídolo Tauris aparece aquí como el símbolo de la deidad del maíz o la fertilidad del maíz. Después de los rituales, una parte de las mazorcas del maíz que llaman misa sara es dedicado para la elaboración de la chicha por los sacerdotes andinos y la otra parte les sirve para las ceremonias del pago, por lo que "queman en sachrifisio".

En los pueblos de la región ya no hacen ceremonias sociales con las mama sara (Madre maíz) y misa sara (Camaquen de maíz), que eran las representaciones espirituales de la comida sagrada del maíz, pero siguen practicando el ceremonioso recojo de las mishas del maíz y de las mama saras, en la forma doméstica. En los pueblos maiceros de Llipa, Raján, Huanri, Acas, Copa se le denomina misha a la mazorca de granos de varios colores: rojos, rosados, azules, amarillos, blancos y jaspeados. Cuando en las cosechas aparecen las 
mazorcas misha, los campesinos no lo consumen de inmediato. Cogen estas mazorcas para colgarlo de sus pancas en los aleros de sus casas y sólo se consumen cuando hay carestía de alimentos. Consideran que las mazorcas misha constituyen la presencia del espíritu del maíz, el camaquen o el illa representado por el mismo maíz en la forma de una exhibición extraordinaria de colores de sus granos considerados sagrados. Lo exhiben en sus alares y no lo consumen porque creen que el espíritu del maíz los ha visitado y eso es un honor para el campesino que lo ha cosechado, significa buena suerte, indica que habrá abundancia de granos en el futuro. Asimismo, queda en las costumbres de estos pueblos coger las plantas del maíz que ha producido varias mazorcas: dos, tres o cuatro en algunos casos. Estas son las mama sara de la que nos habla don Pedro Sarmiento y otros informantes del siglo XVII. Cuando en las cosecha aparecen esta secuencia de mazorcas en una sola planta, los campesinos lo cogen igualmente para exhibirlo en los aleros o en las partes altas de sus casas. Lo consideran que la madre del maíz, les ha favorecido con su presencia, por eso no lo consumen de inmediato, al contrario, lo cuidan por el tiempo que sea necesario en sus casas. Tanto a la misha como a las mazorcas múltiples no le rinden culto alguno, pero lo siguen conservando y reconociendo como a la madre y el espíritu del maíz que cultivan y de la que se alimentan.

\section{Origen de los alimentos en el mito de Canta}

Con similares características contadas por los testigos de San Pedro de Hacas, pero sin mencionar el nombre de la Mama Rayguana, aparece otro mito en la región de Canta, sierra del departamento de Lima. En la versión del mito de Canta, los personajes que interactúan son casi los mismos, con excepción de Rayguana y del yucyuc que en Cajatambo son personajes estelares: la mujer, los niños, el gavilán, el picaflor, las pulgas. Corresponde a la recopilación de Arcadio Arteaga, que en 1976 publica su trabajo, el mismo que es comentado también por Cardich en su monografía de 1981. El mito contado por un informante moderno de Canta dice textualmente lo siguiente:

“...una humilde madre campesina, con sus dos hijos mellizos, buscaba afanosamente algún mendrugo para aplacar el hambre, tanto para los chicos como para ella misma, sin descuidar un solo instante a sus vástagos, porque todo peligraba en esa época de hambruna. Un gavilán que daba vueltas y vueltas con la intención de alimentarse de los mellizos, logró con la complicidad del quencho (colibrí o picaflor) echar unas pulguitas en la orejas de la buena madre, dejándola dormida por largo rato. Aprovechó de esta situación el pillo gavilán para llevarse a los codiciados mellizos, pero en el momento en que se preparaba a devorar a los niños se presentaron las golondrinas, el quencho, el huamán (aguilucho), y muchas aves hambrientas reclamando su parte en el festín. Convinieron entonces en repartirse la ración y para este propósito tenían que dividir a las criaturas en pedacitos de una presita para cada ave. ;Pero he aqui el milagro! Conforme iban dividiendo las presas iban apareciendo los alimentos que se necesitaban... Así, las cabecitas se convirtieron en papas, de los ojos aparecieron los ollucos, de las piernecitas se formaron las ocas, de las uñas surgieron las habas, de las ventosidades el trigo y asi aparecieron todos los alimentos...." (Recopilación de Arcadio Arteaga, citado por Cardich, 1981: 18)

Por sus componentes, el relato de Canta no deja de tener similitud con el mito de la Mama Rayguana de Caina. En este caso, no es el zorzal el artífice del hurto de los niños de los brazos de su madre, es el hambriento cernícalo de las alturas, el gavilán quien trama la estratagema de las pulgas con la complicidad del ágil colibrí, ave que no come carne, vive del néctar de las flores. Tampoco hurtan a las conopas, espíritus germinales de los alimentos, se apoderan de los mellizos para darse un festín con la tierna carne de los infantes. En 
Canta no es la Madre de los alimentos, Mama Rayguana, la que vencida por el yucyuc y el picaflor se ve obligada a repartir las comidas a los habitantes en carestía de alimentos; es el concurso masivo de las aves, tanto rapaces como las inofensivas golondrinas las que obligan al gavilán a compartir la carne de los niños hurtados. En las informaciones recogidas en Hacas (Acas), la Mama Rayguana, madre de los alimentos que repartió todo lo que tenía en custodia se convierte en una deidad progenitora de alimentos, como también el yucyuc, que con su acción logró el ansiado reparto de los conopas; en Canta, de la madre no se tiene más noticias, en cambio las partes del cuerpo de los mellizos se convierten en los alimentos de la sociedad andina, tanto alimentos nativos como la papa, el olluco, la oca, cuanto de alimentos que vinieron de Europa como las habas y el trigo. Por estos componentes, el relato mítico de Canta puede ser propiamente moderno, es decir, colonial o republicano; pero también puede ser una historia mítica de origen prehispánico que ha adicionado elementos nuevos en su estructura. Hay parecido en la estructura general en ambos relatos, pero también tienen sus diferencias. Es probable que se trate del mismo relato mítico de la Mama Rayguana, que el tiempo y la distancia ha ido modificando al relato original. El de Canta parece ser la pervivencia modernizada del mito de la Mama Rayguana.

\section{El mito de Vichama y el origen de los alimentos de la costa}

Cronistas de la Colonia como, Inca Garcilaso de la Vega, Aantonio de la Calancha y otros, han recogido durante el proceso de catequización diversidad de mitos que tienen que ver con la racionalidad de origen del hombre de la costa y el origen de los alimentos. Este es el caso del mito recogido en Végueta, en el valle de Huaura, cerca de Huacho, cuyos argumentos para la región de la sierra aparecen también explicados en el relato del informante llacuaz Hernando Chaupis Cóndor del ayllu de Yanaqui del pueblo de Hacas, arriba mencionado. Végueta es en la actualidad distrito de la provincia de Huaura, situado al norte del departamento de Lima. Este relato es conocido como el Mito de Vichama y es una de las historias orales mejor estructuradas sobre el origen de los hombres y de los alimentos de la región costa. “...i agora diremos a quál (dios) reconociesen los marítimos, que son los Iungas abitadores de los llanos i arenales desde Piura hasta Arica...", dice Calancha al reproducir el mito, recogido por el padre Luis Teruel, catequizador de estos valles. Vichama, hijo del dios Sol es el héroe mítico fundador de la cultura de los pescadores y agricultores de estos valles de la costa central del antiguo Perú. De la crónica del agustino Calancha, reproducimos la versión del Mito de Vichama, con los cambios ortográficos introducidos en la edición de 1976.

Que no abía en el principio del mundo comidas para un ombre i una muger que el dios Pachacamac avía criado, murió de ambre i quedó una sola muger, que saliendo un día a sacar raizes de yerbas entre espinas, con qué poderse sustentar al canpo, alçó los ojos al Sol, i entre abundantes lágrimas, i quexosos suspiros, le dijo al Sol así: "Amado criador de todas las cosas, ¿para qué me sacaste a la luz dl mundo, si avía de ser para matarme con pobreça, i consumirme con anbre? O nunca te acordarás de criarme de la nada, o me acabarás al punto que salí a este mundo, yo sola viva en él sin sucesión de ijos, pobre, aflijida i sola; ¿porqué o Sol, si nos criaste, nos consumes? I ¿cómo, si eres el que repartes luces, muestras ser miserable negándome el sustento? No pareces piadoso, pues no te compadeces de los afligidos, $i$ no socorres a los que criaste tan desdichados; permite, o que el cielo me mate con un rayo, o la tierra me trague acabando tan trabajosa vida, o socórreme benigno, pues me criaste omnipotente. " Estas i otras ternuras i desesperaciones decía afligida al Sol, estímulos de la anbre que cría rabias como dijo Silio Itálico; compadecido el 
Sol bajó alegre, saludóla benigno, y preguntó la causa de su lloro, fingiéndose ignorante; $i$ ella le dijo el afán de su vida, el trabajo de buscar el sustento, entre espinas, i la triste pasadía librada solo en desenterrar raizes; cosa como ésta creyeran los latinos, $i$ la repite Lucano. Oyendo sus lástimas, condolido de sus lágrimas, le dijo palabras amorosas, que depusiese el miedo, que esperase descansos, porque ya no sería causa de sus penas la que asta alli lo avía sido de sus congojas, consuelo que en semejante ocasión repitió Ovidio de sus Dioses. Mandóle que continuase en sacar raizes, i ocupada en esto, le infundió sus rayos el Sol, i concibió un ijo, que dentro de quatro días con goço grande parió, segura ya de ver sobradas las venturas, $i$ amontonadas las comidas; pero salió al contrario, porque el Dios Pachacamac indignado de que el Sol se le diese la adoración devida a él, i naciese aquel ijo en desprecio suyo, cogió al recién nacido Semidios, $i$ sin atender a las defensas i gritos de la madre, que pedía socorros al Sol padre de aquel ijo, y también padre del Dios Pachacamac, lo mató despedaçando en menudas partes a su ermano. Lo mesmo cuenta Ovidio que hizo Medea despedaçando a su ermano Gialeo sembrando sus guesos por los canpos, fratricidio de que a lamentosas voces, i a quejas justas pedía vengança al Sol su padre; pero Pachacamac porque nadie otra vez se quejaxe de la providencia de su padre el Sol de que no producía mantenimientos, ni la necesidad obligase a que a otro que él se le diese la suprema adoración. Sembró los dientes del difunto i nació el maiz, semilla que se asemeja a los dientes, sembró las costillas $i$ guesos, nacieron las yucas, raiz que redonda tiene proporción en lo largo i blanco por los guesos, i las demás frutas desta tierra que son raizes. De la carne procedieron los pepinos, pacayes, $i$ lo restante de sus frutos $i$ árboles, $i$ desde entonces ni conocieron anbre, ni lloraron necesidad, debiéndosele al Dios Pachacamac el sustento $i$ la abundancia, continuando de suerte su fertilidad la tierra, que jamás a tenido con estremo anbres la posteridad de los Iungas. No se aplacó la madre con estas abundancias, porque en cada fruta tenía un acordador del ijo, i un fiscal de su agravio; $i$ asi su amor y la vengança le obligaban a clamar al Sol, i a pedir o el castigo o el remedio de sus desdichas, como de otra cantó Virgilio, bajó el Sol no poderoso contra el ijo Pachacamac, sino condolido de la muger que le lastimava; i preguntándole donde tenía la vid i onbligo del ijo difunto, se le mostró, $i$ el Sol dándole vida criá otro ijo, $i$ se le entregó a la madre, diciéndole: "toma $i$ enbuelve en mantillas este niño que llora, que su nombre es Vichama" crió al niño que creció ermosísimo, asta ser bello i gallardo mancebo, que a imitación de su padre el Sol, quiso andar el mundo, i verlo criado en él, consultó a la madre i continuó su viage; no uvo bien començado su ausencia, cuando el Dios Pachacamac mató a la que ya era vieja, i la dividió en pequeños troços, i los izo comer a los cuervos Indicos que llaman gallinaços, $i$ a los buytres Peruanos que llaman cóndores; i los cabellos i guesos guardó escondidos en las orillas del mar; crió onbres i mugeres que poseyesen el mundo, i nombró Curacas i Caziques que lo governasen. Bolvió el Semidios Vichama a su patria, que se llama Végueta, valle abundante de arboledas, i ermoso país de flores, conjunto una legua poco más o menos de Guaura. Deseoso de ver a su madre no lo alló, supo de un Curaca el cruel castigo, i arrojavan fuego sus ojos de furor, i llamas su coraçón de sentimiento, al modo que pintó Virgilio el enojo del otro, convocó los que abituaban aquellos valles. Preguntó por los guesos de su madre, supo donde estaban, fuelos conponiendo como solian estar, i dando vida a su madre la resucitó a esta vida, i trató de la vengança, porque sólo ella aplacaría su furor, como de otro dijo Ovidio, i fue disponiendo el aniquilar al Dios Pachacamac, pero él por no matar a estotro ermano, enojado con los onbres, se metió en la mar en el sitio i parage donde aora está su templo, i oy el pueblo i valle se llama Pachacamac de quien vamos ablando. Viendo el Vichama que se le avía escapado el Pachacamac, bramando encendia los ayres, $i$ centellando atemorizava los canpos, como del otro dijo Persio, bolvio el enojo contra los de Vegueta, i culpándoles de cónplices, no 
porque mataron, sino porque permitieron, i quando no cooperasen en el castigo, se alegrarian de la muerte, llevado de un repentino furor, sin admitir disculpas, ni mitigar ser con ruegos, pidió al Sol su padre los convirtiese en piedras, conversión que luego se izo. Viéndose en piedras convertidos, las criaturas que formó el Pachacamac ya invisible, para que se vea quan dificultoso es a los Dioses falsos aplacar la ira una vez atizada, como dijo Séneca, pagando los onbres las culpas de tal Dios; dichosos los que confiesan que Jesu Cristo las nuestras. No uvo bien ejecutado el castigo el Sol i el Vichama, quando se arrepintieron de la inpiedad, que lo que la ira yerra, $i$ el arrepentimiento no puede emendar, lo castiga el dolor de averlo echo, i la apena de no allarle remedio como dijo Oracio. El Sol i el Vichama no pudiendo desazer el castigo, quisieron satisfacer el agravio, i determinaron dar onra de divinidad a los Curacas i Caziques, a los nobles i a los valerosos, i llavándolos a las costas i playas del mar, los dejó a unos para que fuesen adorados por guacas, $i$ a otros puso dentro del mar, que son los peñoles, escollos o euripos, a quien les diesen títulos de deidad, $i$ cada año ofreciesen oja de plata, chicha i espinco, con que se aplacasen los tales convertidos, dando el primer lugar al Curaca Anat, que es un peñol o roca, una legua de tierra rodeada del mar, por ser éste el mayor que entonces era de los onbres (i por esto es oy el de mayor adoración entre los Indios) viendo el Vichama el mundo sin onbres, i las guacas i el Sol sin quién los adorase, rogó a su padre el Sol criase nuevos onbres, i él lo enbió tres guevos, uno de oro, otro de plata, $i$ otro de cobre. Del guevo de oro salieron los Curacas, los Caziques, i los nobles que llaman segundas personas i principales; del de la plata se engendraron las mugeres destos, $i$ del guevo de cobre la gente plebeya, que oy llaman Mitayos, $i$ sus mugeres $i$ familias. Este principio creían como si fuera artículo de Fe todos los Indios de Guaura, de Cupi, de la Barranca, de Aucayama, de Guacho, de Vegueta, i los que abitan la costa, como se averiguó por el Visitador Fernando de Avendaño i por los padres Pablo Josep de Arriaga, i Padre Luis Teruel, i los Indios desde Caravaillo cinco leguas de Lima al norte, i Pachacamac cinco leguas al sur, i los pueblos que corren la costa al mediodía asta Arica.... (Versión textual de Antonio de la Calancha, 1976, p. 930 - 935)

Hay varios mensajes de los tiempos antiguos de la costa peruana en este extraordinario mito de Végueta. Damos atención preferencial a tres de sus componentes principales: las relaciones conflictivas de los dioses, el origen de los hombres de la costa y el origen de los alimentos, sobre los que gira la estructura básica del relato de Vichama. Figuran en el discurso tres dioses de jerarquías diferentes: el Sol, dios creador principal que mora en el firmamento; Pachakamaq, dios creador que gobierna en la tierra, hijo del dios Sol y Vichama, también hijo del dios Sol y hermano menor de Pachacamac, de madre terrenal creado por Pachakamaq. La mujer y su pareja viven en estado salvaje, abandonados por su creador, alimentándose de raíces y otras formas de recolección. El hombre muere de hambre, pero la mujer sobrevive lamentándose e increpando al Sol por su desdicha en la tierra. Condolido por las quejas y súplicas de la mujer, el dios Sol baja a la tierra y fecunda un hijo en el vientre de la mujer, que nace a los cuatro días y alegra la vida desdichada y solitaria de la mujer. Como en los dioses del Olimpo, los dioses andinos también entran en conflicto. Por celos, Pachakamaq mata al semidios recién nacido, su primer hermano, y temeroso de la venganza del Sol entierra el cuerpo del infante en los arenales. Calancha compara frecuentemente los pasajes conflictivos de los diosos costeños con los mitos greco-romanos muy bien conocidos por él.

Aunque tardíamente, Pachakamaq quiso remediar el hambre de la mujer con los restos trozados del niño, su hermano. Aquí es donde entra el segundo tema del origen de los alimentos, cuando el dios de la tierra siembra las partes del cuerpo del semidios asesinado. De sus dientes nacieron las mazorcas del maíz; de sus costillas y huesos nacieron las yucas, 
y otros frutos; de sus carnes nacieron los pepinos, los pacaes y las plantas, con los que desapareció el hambre y se hizo presente la abundancia. Los celos del dios Pachakamaq, contra su padre el Sol, le lleva al infanticidio divino, pero al mismo tiempo resuelve el problema de la hambruna con los miembros de su hermano asesinado. Por esta causa, el dios Pachakamaq aparece en este mito como el primer creador de la especie humana en la costa y también como el creador de la domesticación de las plantas alimenticias, utilizando la fuerza vital del hijo del dios del firmamento. Pero el conflicto de las divinidades continúa, porque la mujer no olvida el deosidio de Pachakamaq, que los alimentos creados lo avivan constantemente, por lo que sigue reclamando ante el Sol el justo castigo. El astro dios baja a la tierra con la intención de castigar a Pachakamaq, que al verse perseguido se oculta en las profundidades del mar donde los rayos del sol no podrán penetrar. Al no encontrarlo, engendra un segundo hijo con el ombligo del primer hijo, a quien le da el nombre de Vichama. Este nuevo semidios estará protegido por el padre Sol y por la madre luna, por lo que su vida será larga, de muchas y largas aventuras en la tierra.

Cuando Vichama regresó a Végueta de su largo peregrinaje por el mundo en busca de su madre, encuentra que las cosas han cambiado en su tierra de origen. No hay una sola choza como él conocía sino muchas chozas, con mucha gente nueva que nunca conoció. Se entera que su anciana madre ha sido asesinada por el malvado Pachakamaq y va en busca de él para vengarse, pero tampoco lo encuentra. El primogénito del dios Sol se ha sumergido nuevamente al mar para quedarse en sus profundidades para siempre. Al no poder hacer justicia por sus propias manos, convierte en piedras a todos los hombres creados por Pachakamaq. Luego, junta los huesos de su madre y lo vuelve a la vida, joven y lozana, con lo que retorna la alegría de Vichama. Con la intervención de su padre el Sol, las criaturas de Pachakamaq convertidas en piedras pasan a ser huacas venerables, tanto en la parte continental como en las islas de mar adentro. La isla frente a Végueta personifica al curaca Anat, así como la isla frente a la desnvocadura de río Lurín representa al dios Pachakamaq, que se convierten en huaras veneradas por los habitntes costeños de estos valles.

Pachakamaq viene a ser, según el mito, el primer creador de la pareja humana costeña, al infundirle vida a una mujer y a un hombre, que luego es abandonado a su suerte en la tierra de abundante vegetación, pero sin conocimiento de la domesticación de plantas ni de animales, probablemente los antecesores primitivos de los habitantes de Caral; ${ }^{26}$ es también el creador de muchos hombres y mujeres, con sus caciques y mandones que hacen todo un pueblo en Vichama y en Végueta, que luego el semidios Vichama los convierte en piedras, en venganza al pérfido Pachakamaq. Vichama, en su condición de deidad preferida del dios Sol, es el creador, junto con su padre, de hombres y mujeres de una nueva generación culturalmente más avanzada, que se quedan a vivir en estos ubérrimos valles "abundante de arboledas i ermoso país de flores", en nuevas condiciones de abundancia de alimentos, que han aprendido a crearlas con su trabajo. No menciona el mito, pero todo parece indicar que con Vichama, la nueva población creada por ellos, inventa la agricultura en tierras húmedas. Siempre con la fuerza divina de su padre el Sol, Vichama crea la humanidad para que la tierra esté debidamente poblada. Esta nueva población nace de tres huevos que el dios de los cielos deja caer del firmamento: del huevo de oro nacieron los kurakas, los nobles y las segundas personas, de acuerdo a la lógica de la bipartición andina de arriba y de abajo; del huevo de plata nacieron las mujeres para emparejar con los hombres de las clases altas; del huevo de cobre nacieron los plebeyos y sus mujeres, la gente del pueblo, los que cumplirán con las mitas en el proceso de producción de recursos de vida. Por esta

26 La cultura Caral, situada en el valle de Supe, es considerada por la arqueóloga Ruth Shady, de una antigüedad de 2600 años a.C. 
última parte del discurso mítico, el dios creador de los hombres de la costa con cultura creada por la energía humana es definitivamente Vichama. Las tres categorías de seres humanos que expresa el mito parecen estar en correspondencia con la estructura social inca, que distinguía a la nobleza del sapa inca y al sacerdocio como pertenencientes a la esfera superior y al jatun runa o pueblo en el extremo inferior del orden social, considerando a las capas intermedias constituidas por administradores y soldados del Tahuantinsuyo. Pero también, este discurso es concomitante con el pensamiento y la estructura de las sociedades europeas del siglo XVI, a la que pertenecían los sacerdotes y soldados de la colonia, que interpretaron a su modo las declaraciones de los informantes vencidos durante la invasión española. Lo importante es que en este relato mítico se encuentran comprimidos los tiempos del salvajismo, la barbarie y la civilización. La fase de los recolectores está simbolizada con la primera mujer que se alimenta de raíces entre las espinas; la agricultura, es decir, la domesticación y consumo de plantas alimenticias como la yuca, los pepinos, los pacaes, aparecen comprimidos en los huesos y carnes del segundo hijo del dios Sol asesinado por su hermano Pachakamaq; las ideas y creencias, así como el orden social y las jerarquías sociales devidamente constituidas de una sociedad costeña de cultura avanzada como en Caral, están referidas en las creaciones divinas a través de los tres huevos: de oro, plata y cobre. Esta es la virtud del mensaje temporal de los mitos andinos.

\section{Danza de la Mama Rayguana en Huánuco}

Mama Rayguana no sólo es un discurso mítico de los antiguos pobladores de los Andes centrales del Perú, es parte de la aparición de los alimentos y por eso sigue viva en la vida cotidiana del hombre del campo: como el tubérculo más preciado por los campesinos de hoy y como una de las representaciones danzísticas emblemáticas de las fiestas populares de los pueblos de esta región. Como madre de las papas, sigue siendo uno de los tubérculos más codiciados por los agricultores y por todos los consumidores de este producto oriundo de los Andes peruanos, por la belleza de su color rosado, su arenosidad interna cuando está cocida y también por su forma ligeramente alargada, de ojos más o menos abundantes. A pesar de que por la comercialización cada vez más intensa de la papa hacia los mercados nacionales e internacionales, las distintas variedades de papa se hibridan en busca de mayor productividad y rápida cosecha, las variedades nativas de la papa rayguana o rayhuana se conserva genéticamente originaria, especialmente en las comunidades campesinas donde la comercialización de papa es de menor cuantía y en las poblaciones donde los campesinos siembran sólo para el autoconsumo familiar, diferenciándolo de los productos que siembran para la venta. En estas localidades de Ancash y Huánuco, la papa rayhuana se conserva en su variedad originaria, junto con otras valiosas especies de papa, como la papa lucha (arenosa de color amarillo), el chingus (arenosa de color blanco), el pumapa maquín (mano de puma), la ishcu puru (poronguito de cal), la hallqa huarmi (mejer de puna), la morada shongo (corazón morado), la llumsuy huaganan (la que hace llorar a la nuera) y otras variedades que los estudiosos han registrado ${ }^{27}$, cuyos nombres son conocidos por los mismos campesinos.

\section{Caracteristicas de la danza}

Varios autores han escrito sobre la danza de la Mama Rayguana, que tiene vigencia en muchas poblaciones de los departamentos de Huánuco y Pasco, en variantes por poblaciones específicas $^{28}$. Ésta es una danza que ha echado raíces en las fiestas patronales, especialmente

27 El Centro Internacional de la Papa (CIP) es la organización científica que mejor ha estudiado a la papa en sus diversas variedades, nativas e híbridas, tanto en el Perú como en varios países del mundo.

28 Víctor Domínguez Condezo, Danzas e identidad nacional, 2003. 
en la fiesta del Corpus Christi del mes de junio, donde concurren una variedad de danzas de distintos tipos. Augusto Cardich (1981) hace varias referencias de la escenificación de esta danza, desde su experiencia de vida infantil en La Unión, capital de la provincia Dos de Mayo, Huánuco. Cuenta que en las fiestas de los pueblos de las provincias de Ambo, Huamalíes, Daniel A. Carrión y en los pueblos del valle de Chaupihuaranga constituyen parte de las escenificaciones coreográficas en las fiestas. A La Unión llegaban estas danzas durante las Fiestas Patrias desde los pueblos menores de Margos, Chaulán y otros, dice Cardich. Refiriéndose a la danza de la Mama Rayguana que conoció de niño, informa Cardich: “...era una de las más llamativas, con una fila de bailarines portando cada uno diversos frutos, como choclos, papas, calabazas, y siempre un ave disecada." (Op. Cit.: pág. 13). Los danzantes de hoy ya no llevan aves disecadas, las aves están talladas en la corona que llevan sobre la cabeza. En cambio, la papa, el maíz y otros productos agrícolas andinos cuelgan de la cintura de las mujeres que bailan formando grupos de parejas.

Por el trabajo etnográfico de Victor Domínguez Condezo (2003), tenemos información que la danza de Mama Rayguana se representa en varias poblaciones de Huánuco y Pasco y continúa manteniendo su mensaje mítico de ser la madre de las comidas. Su simbología aparece en las vestimentas, en las coreografías y en la fecha alusiva a la maduración de las cementeras del mes de junio, aunque en algunas poblaciones se baila en otras fiestas del año, en homenaje a los santos patronos del calendario cristiano. La representación de la Mama Rayguana o la Mama Pacha como sostiene Domínguez Condezo o la Mama Micuy (Madre comida) como lo siguen mencionando en Acas y en los pueblos del antiguo Cajatambo, es representada siempre por una mujer. En la mayoría de los casos se visten de rosado, que es el color original de la pulpa de la papa rayguana, complementado de blanco y otros colores. De la cabeza, el cuello o de la cintura cuelgan mazorcas de maíz, de papas de distintas variedades; sobre la cabeza llevan una especie de corona de madera, en la que se han tallado miniesculturas de aves, en las que aparecen el cóndor, el picaflor, el zorzal (Yucyuc o yuquish), el gorrión. En algunas variantes de la danza, la Mama Rayguana lleva en las manos una canasta con distintos productos alimenticios, que durante el baile va dejando caer al suelo para que la gente lo recoja como signo de buen augurio en las cosechas del año. En todas ellas está la simbolización del mito: la figura de la Mama Rayguana portando las conopas de las comidas, ya sea colgado sobre su cuerpo, tallado en su corona de madera o en el contenido de la canasta. Aparecen también las aves que hurtaron las conopas para saciar el hambre de los hombres o que se juntaron todos para pedirle al dios Pachacamac que aplaque el hambre de la gente como consecuencia de una larga sequía, provocada por el alejamiento de las comidas en protesta por el maltrato de los hombres, como cuentan los yachaj modernos de Huánuco que Domínguez ha recogido. Todas estas formas de representación no están en proceso de folklorización ni en extinción, forman parte de la cultura inmaterial viva, y por tanto constituyen parte importante de las prácticas culturales de los pueblos de esta parte del país, que no han olvidado que la Mama Rayguana es la madre criadora de las comidas. Se han perennizado en los rituales de las fiestas tradicionales, como una forma de guardar memoria de una de las deidades importantes de los antepasados sobre el alma de las comidas que propició la continuidad de la vida de los hombres en la abrupta tierra andina.

Domínguez Condezo ha recogido en el pueblo de Coquín, provincia de Ambo (Huánuco), el mito que argumenta el origen de la danza de la Mama Rayguana. Según su interpretación, esta danza comenzó a practicarse, cuando según el mito, los alimentos volvieron después de una larga hambruna ocurrida en la tierra, después de haberse ido en protesta por el maltrato que le hacían los hombres. La versión del mito fue originalmente 
recogida en quechua y luego ha sido transcrito al castellano e interpretada la versión por el estudioso huanuqueño, en estos términos:

“... antiguamente hubo una hambruna terrible porque los hombres habian maltratado a las comidas. Les hacían llorar. A las papas les quemaban en las ollas, exponían al hielo para hacer el chuño, al pelarlas agujereaban sus ojos o hacía picotear con las aves; al maiz lo tostaban vivitos en las "canalas" y a las ocas las secaban al sol. A las pobres comidas las tiraban al suelo, hacian pudrir o sancochaban por ollas para botarlas.

La papa, el maiz, la oca, el olluco y otros se resintieron y sufrieron mucho. Dieron aviso a Pachakamag y desaparecieron. Una fuerte helada quemó a las hierbas, un mal viento deshojó a los árboles y una hambruna general asoló a los pueblos. El sol secó el sembrío. Las nubes y las lluvias se alejaron por años, desaparecieron los manantiales y las chacras se tornaron polvorientas. Los animales y los niños lloraban de hambre y cientos de aves murieron de sed. Los hombres escarbaron las raices del ayrampo, rangún y otras yerbas para comer.

Un día los animales se reunieron y acordaron nombrar una comisión de aves para entrevistarse con Pachakamag y suplicaron el regreso de los alimentos. El cóndor, seguido del águila, el picaflor y otros fueron haciendo una cadena en el espacio. Volando fueron. Los demás se quedaron preparando el terreno. "Por culpa de los hombres padecemos de hambre", le dijeron a Pachakamag (Creador del mundo). Pachakamag compadeciéndose de las criaturas perdonó a los malhechores y devolvió semillas a la delegación de aves. Todos los animales mirando al cielo nomás estaban. Derrepente, a lo lejos, vieron que estaban regresando, cada cual con una semilla en sus picos. El cóndor traía la papa, el gavilán traía el maíz, el picaflor la quinua, y así cada uno según su tamaño y preferencia. Los demás animales, comedidos y con gran amor, recibieron las semillas que iban cayendo una a una. Sembraron con extrema alegría y cultivaron con mucho cariño. Cantaron y bailaron cuando nuevamente hubo cosecha, gracias a la fecundidad de la Mama Rayguana (Mama pacha) que hace nacer, crecer y madurar a las plantas.

Desde entonces, el león, el puma, el oso, el waychau, huayanay, jillish, gorrión y todos los animales danzan contentos en torno a la Mama Rayguana, festejando el paso de la hambruna a la abundancia. Por eso hasta ahora, de pueblo en pueblo escenifican la danza de la Mama Rayguana. A las semillas de la papa, del maíz, la oca, etc. hacen cariñar con la Rayguana para que sean fecundas. Desde entonces, los hombres amaron a las comidas y construyeron collqas, pirhuas, altillos para guardar sus cosechas y no tener hambre. De algunos pueblos Mama Rayguana se está yendo, llevándose las comidas, porque están olvidando de presentar la danza de la Mama Rayguana. Si los hombres vuelven a maltratar a la papa, al maiz, a la oca, y a los demás alimentos andinos, nuevamente vendrá la hambruna como vino antes." (Interpretación del quechua de Víctor Domínguez Condezo; 2003: 26 y 27).

Esta es otra ingeniosa versión del mito sobre la Mama Rayguana, recogida también en Huánuco, en la que la madre papa representa a la pacha mama (madre tierra). El poseedor de los alimentos es aquí Pachakamaq, el dios creador del mundo, quien castiga a los hombres con la hambruna por los maltratos a las comidas y luego los perdona y envía nuevamente las semillas para que vuelva la abundancia, gracias a la fecundidad de la pacha mama. En la versión de Acas, el héroe para la llegada de la abundancia es el yucyuc y su ayudante, el veloz y pequeño picaflor, quien se encarga de llevar las pulgas para distraer a la Mama Rayguana; en el relato de Coquín los héroes son la comisión de aves que vuela hasta la residencia de Pachakamaq y retorna con las semillas de las comidas en el pico de cada uno de ellos. En el mito de Acas el yucyuc se convierte en semidios por su hazaña a favor de los 
hombres; en la versión de Coquín la comisión de aves no recibe la categoría de deidades a pesar de haber logrado el retorno de los alimentos y con ellos la abundancia.

Según la secuencia del mito de Coquín, son las aves y otros animales los que hicieron volver a los alimentos y son al mismo tiempo creadores de la danza alrededor de la Mama Rayguana, en demostración de alegría por el fin de la hambruna que provocaron los hombres, en la que participa también el león, un animal de las selvas africanas. Los hombres habrían imitado la alegría de los animales, bailando la danza de la Mama Rayguana, como un gesto de agradecimiento a la pacha mama, representado por la Mama Rayguana. Para el informante de Coquín, la abundancia de alimentos lograda por la comisión de aves no será para siempre, está condicionada a la fidelidad y constancia de continuar danzando en honor a Mama Rayguana. Si los hombres que consumen estos alimentos andinos dejaran de danzar y olvidaran la tradición de rendir culto a la madre de las comidas, Mama Rayguana se irá nuevamente con el espíritu de los alimentos y volverá la temida hambruna. Extraordinaria lógica campesina de los Andes peruanos, que se encuentran permanentemente temerosos de los ciclos de sequía, que le llega cada vez que al fenómeno del Niño se le ocurre pasar por esta parte del continente o cuando el calentamiento de la tierra de estos tiempos provoca fenómenos desconocidos de excesivas lluvias, vientos huracanados, sequías prolongadas, sunamis, plagas y otras desgracias cada vez más devastadoras.

\section{Origen mítico de los manantiales Capabilca y Corcuycallán}

En la literatura oral andina existe también abundante material mítico que explica el origen de los fenómenos naturales: montañas, ríos, lagunas. Según el mito, las montañas emblemáticas de Ancash, conocidas como las cordilleras blanca y negra tienen su explicación. César Ángeles (1988) y Marcos Yauri (2000) han recogido, cada uno a su modo varios mitos sobre la cordillera blanca. Según Yauri, el valle del Huaylas era una amplia planicie que se proyectaba hasta los Conchucos. Por los constantes daños de las llamas y alpacas de los vicosinos en los dominios de los conchucos creció la discordia. Por esta causa, el cacique de Huaylas ordenó a sus subditos amontonar tierra en sus linderos. Con los años, la cantidad de tierra creció tanto que tocaba el cielo y por las noches chocaba con la madre luna. Por su gran altitud, se cubrió de nieve y desde estos nevados aparecieron los manantiales, los ríos y las lagunas. Así nació la cordillera blanca que separó definitivamente a los de Vicos de sus vecinos los conchucos. Sobre el origen de los picos nevados del Huandoy y del Huascarán, César Ángeles y Marcos Yauri transmiten el mito de los amores de la princesa Wandy y del guerrero Huasca o Huascar. Con esta relación amorosa no estaba de acuerdo el padre de Wandy, pero a pesar de la prohibición impuesta por él, la princesa continuó prendada de Huasca y escapó con su amado. Perseguida y entregada al curaca encolerizado, los enamorados fueron amarrados en lo más alto de las montañas, uno frente al otro. Con el tiempo ambos enamorados se helaron y se convirtieron en montañas nevadas: una con el nombre de Huandoy y el otro con el de Huascarán, como quedan hasta hoy. En otro relato mítico de Ancash, se explica el origen de las lagunas, como el caso de la laguna de Alpamayo $^{29}$, que se originó con las lágrimas de la princesa Alpamayo, por el hechizo cometido contra su pretendiente y luego esposo, el príncipe Alpachayllu, por los envidiosos conchucos que lograron que cambie sus sentimientos por una bella conchucana. Las lágrimas acumuladas de la princesa por la larga espera de su querido esposo crearon la laguna de Alpamayo.

29 Marcos Yauri, Leyendas ancashinas, 2000: p. 21-22. 
En la provincia de Jauja, la memoria colectiva de estos pueblos, explica con mucha precisión el origen mítico de la laguna de Paca. Según este mito, el lugar donde está la laguna era antiguamente un centro poblado ocupado por gente malvada, que vivía en constante discordia, envidia y desenfreno social. Dios envió un mensajero para que avisara al más justo de los personajes, que para salvarse de una calamidad debía alejarse por los cerros, sin voltear la mirada hacia atrás, aún cuando escuchara ruidos estrepitosos. En efecto, el personaje escogido, escuchó en su huída hacia las alturas, grandes voces de alegría, música y jolgorio que lo tentaba a voltear para ver lo que en realidad pasaba. Al voltear la mirada hacia abajo vio que sobre el pueblo caía una tempestad y torrencial lluvia, que rápidamente cubrió a toda la población y lo convirtió en una laguna como es ahora. Por no haber obedecido el mandato de dios, el personaje escogido quedó convertido en piedra. Este tipo de relatos aparecen en varios lugares del país, donde la laguna era en el pasado una población que luego es castigado por la divinidad. En Jauja y en otras regiones del país, la explicación mítica del origen de las lagunas naturales tiene más o menos la misma estructura, como lo ha demostrado en sus trabajos el antropólogo Efraín Morote Best. ${ }^{30}$

El origen de los manantiales, tan apreciados en territorios donde la escasez de agua para el consumo y para el riego es agudo, se explica igualmente mediante el discurso de los mitos andinos. Para ilustrar este tema de los manantiales volvemos una vez más al pueblo de Hacas colonial, de donde provienen los más interesantes relatos míticos de la cosmovisión andina del siglo XVII. En efecto, para los indigenas de Hacas del antiguo Cajatambo, la existencia de cinco puquiales de su pueblo están precisamente explicadas en el interesante mito de dos héroes fundadores de la agricultura de riego en este pueblo de magníficos cultivadores de papa: Capabilca y Corcuycallán. Esta vez el relato pertenece a la memoria de Christobal Hacas Poma, sacerdote del ayllu de Chaca, principal del pueblo de San Pedro de Hacas, hermano menor y uno de los prominentes discípulos de Hernando Hacas Poma. Forma parte de la declaración hecha ante el visitador de idolatrías Bernardo de Noboa, el 24 de enero de 1657:

“... asi mesmo dijo que en el ayllu de Canta está un ydolo llamado Corcuicallan era guaca del ayllu Quirca y despues bino el ydolo Capabilca peleo con el dicho Corcuicallan por quitarle las chacras que poseia y este Corcuicallan quando peleaba se conbertia en laguna de sangre y ambos a dos ydolos por donde pasaban abrian las peñas dejando calles abiertas en ellas y que en aquel sitio de Quircas ai unos callejones en el mesmo cuerpo del cerro que son las señales que dejaron estos dichos ydolos y biendo que eran igualmente balientes dijeron veamos quien tiene mayor poder para hacer puquios y el dicho Corcuicallan orino en dos partes y salieron dos puquios llamados oco puquio y cucri puquio que están en las chacras deste ayllu y Capabilca orino en tres partes y salieron tres puquios deste ayllu llamados Vicri pampa culcucocha y Muchac puquio que estan tambien junto a las chacras deste ayllu con que las riegan y mochan los deste ayllu con cuyes bibos que les ofrecen a estos dichos ydolos conosiendo el poder y sabiduria que tenian se hisieron amigos y repartieron las chacras entre si y cuando murieron se convirtieron en piedras y los deste ayllu an mochado siempre estos ydolos. Y asi mesmo dijo que hacia el camino distaban dos leguas deste pueblo de Hacas estan dos malquis llamados Yumarachin y Micuchin Libiac que eran hermanos y adoran y mochan los yndios llacuaces del ayllu Yanaqui y en el ayllu Carampa en el pueblo viejo estan por sacar los ydolos conopas llamados Papa Conopa y Sara Conopa y Llama Conopa..." (Expediente XI, legajo 6 del Archivo Arzobispal de Lima).

30 Efraín Morote Best, en su libro Aldeas sumergidas, 1988, explica con varios ejemplos bíblicos y peruanos acerca de mitos en los que aparecen pasajes de la salvación del hombre caritativo y el tabú de no mirar hacia atrás, así como la conversión de pueblos en lagunas y de hombres en piedras. 
En las tierras de Acas, uno de las comunidades que posee un amplio territorio que cubre varios pisos ecológicos: puna, suni, quichua y yunga (cabecera de costa), existen muy pocos manantiales para el riego ${ }^{31}$. Por esa escasez de agua, los antiguos pobladores huaris construyeron un largo canal de riego, desde la puna hasta el pueblo de Acas, para captar las aguas de la laguna de Condorcocha. Otro canal de riego fue construido por ellos desde el abra de Qais, para irrigar las tierras maiceras de zona quichua. Los pocos manantiales de la zona suni y quichua de Acas, se originan, según el mito, por los héroes fundadores de la agricultura de la etnia huari: Capabilca y Corcuycallán. Según el mito, estos primeros pobladores eran personajes poderosos, capaces de partir cerros y peñazcos como aparecen “...en aquel sitio de Quircas (donde) hay unos callejones en el mesmo cuerpo del cerro..." Capabilca aparece en principio como opositor de Corcuicallan en el control de las tierras de cultivo y fueron enemigos por la posesión de tierras, por lo que tuvieron que competir de varios modos para mostrar sus poderes. La contienda final consistió en crear mayor cantidad de manantiales. Con este propósito, ambos personajes orinaron en los cerros y con la orina crearon manantiales o puquiales, es decir, ojos de agua para el riego de las cementeras en las chacras. Por este juego de poderes, el cultivo de cementeras con el aprovechamiento sólo de las temporadas de lluvia, Corcuicallan y Capabilca, dan paso a la agricultura de riego en estos ayllus donde Hacas era la cabecera de ayllus. Ambos contendientes eran poderosos y al orinar en la competencia crearon los manantiales. Según la versión de Christobal Hacas Poma, la pertenencia de estos semidioses a los ayllus de la época y los manantiales que crearon aparecen en este orden:

\section{Corcuicallan: ayllu de Canta}

Puquios: Oco puquio y

Cucri puquio.

\section{Capabilca: ayllu de Quircas}

Puquios: Vicri pampa

Culcu cocha y Muchac puquio.

Lo importante es que al comprobar que los dos héroes tenían poderes iguales, hicieron las paces y se "hicieron amigos", se dedicaron a repartir las tierras a los habitantes y a enseñarles la agricultura de riego. Al morir, ambas héroes "se convirtieron en piedras". Desde entonces, fueron adorados como semidioses por los habitantes de esos ayllus y en fechas específicas les rendían culto, con los consabidos sacrificios de cuyes, sebos, coca y todos los elementos sacralizados para estar en armonía con las divinidades fundadoras de su cultura material.

Christobal Hacas Poma da cuenta también de las huacas y adoratorios de los llacuaces que vivían en las zonas altas de esta localidad. Distingue claramente a los ayllus huaris dedicados a la agricultura de riego y a los llacuaces pastores de puna, que habiéndose fusionado culturalmente después de un período largo de tiempo, como explica Duviols ${ }^{32}$, en Acas vivían todavía separados y sin la beligerancia que les caracterizó en tiempos pasados. Los mallquis de los hermanos Yamarachin y Micuchin, también héroes fundadores de la etnia de los llacuaces son asimismo adorados por los indios de los ayllus de Yanaqui y de Carampa. Son los continuadores de los antiguos cazadores y pastores que ocuparon las planicies y pastales por debajo de los nevados de Keushapa ${ }^{33}$ y de las inmediaciones de las lagunas de Condorcocha y Tillishcocha, que a la llegada de los estirpadores seguían recibiendo honores religiosos, tanto como a Corcuicallan y Capabilca, mallquis creadores

31 Melinda Martínez Cano (2005) se apoya en estos héroes de Acas para fundamentar su artículo acerca de los muchos manantiales de la comunidad campesina de Parco en el valle del Mantaro.

32 Pierre Duviols (1973) sostiene la tesis del dualismo prehispánico de oposición entre agricultores y pastores y la complementariedad cultural como consecuencia de la fusión entre huaris y llacuaces.

33 Keushapa es la montaña más alta en los territorios de Acas, con aproximadamente $5000 \mathrm{msnm}$, que hasta los años sesenta estaba cubierto de nieve. Por el calentamiento global han desaparecido las nieves. 
de los puquiales de los ayllus conformados por los agricultores de las zonas intermedias. Otras deidades de las comidas y de animales son también confirmadas por Christobal Hacas Poma. Menciona en su declaración acerca de los ídolos de las conopas más representativas: "Papa Conopa Sara Conopa Llama Conopa"; es decir, los espíritus germinales de la papa, del maíz y de la llama, que están "en el pueblo viejo". Probablemente se refiere al pueblo antiguo, cuyos restos arqueológicos están en la colina noroeste de Acas, donde habrían fijado su residencia originaria, antes de establecerse en la parte plana donde se encuentra el asentamiento humano que visitó Noboa y que sigue siendo hasta hoy la población de Acas. Por estos importantes datos tenemos claridad hoy con respecto a la ubicación del antiguo Hacas y de la jerarquía de sus deidades locales: Corcuicallan y Capabilca como héroes-dioses fundadores de los huaris agricultores y Yamarachin y Micuchin, también como dioses-héroes fundadores de los pastores llacuaces, cuyos mallquis se conservaban para el culto colectivo de sus descendientes, así como de los conopas de la papa, del maíz y de la llama, que también conformaban el corpus general del panteón de los habitantes de la región norte de Cajatambo a mediados del siglo XVII.

\section{Construcción de la memoria colectiva}

¿Cómo se explica la solvencia narrativa de testimonios de los indios procesados en las tenebrosas sesiones dirigidas por los extirpadores de idolatrías? En la mayoría de los casos, los testigos son sacerdotes y sacerdotizas de distintas jerarquías los que desfilan en estos procesos. Ellos estaban convenientemente preparados para exponer la memoria histórica de sus pueblos, construidos mediante la transmisión de los saberes de generación a generación. Transmitir los conocimientos, preservar las tradiciones en el tiempo e infundir las identidades, requirió de mecanismos especiales en las sociedades prehispánicas, tanto en la etapa de los incas como en las sociedades que la antecedieron. La forma más conocida y contundente de conservar hechos del pasado y rigurosas estadísticas de la sociedad, de la economía y de la infraestructura inca ha sido a través del kipu o quipu ${ }^{34}$, un sistema secuencial de hilos anudados, adheridos a una base horizontal, que los españoles destruyeron en los mismos recintos donde se conservaban, pero que no pudieron borrar del todo los conocimientos adquiridos para relatar y contabilizar acontecimientos y datos de recursos existentes en los cuatro suyos del Tahuantinsuyo. A través de los datos consignados en las cuerdas, confeccionados por contadores y estadígrafos especializados, el inca podía tener información precisa de lo que acontecía en todo el imperio y podía comparar los datos del momento con los datos del pasado, de los tiempos buenos y de los malos, de los triunfos y de las derrotas, de las buenas cosechas y de la tenencia de ganado en las diferentes regiones de sus dominios (Murra, 1975; Radicati, 1979).

\section{Mecanismos de comunicación}

La escritura no es el único recurso para transmitir hechos y acontecimientos sociales para la posteridad, es uno de los más importantes medios de comunicación que el hombre ha inventado hace más de 5000 años $^{35}$. Antes que aparecieran las distintas formas de escritura y aún después de esos descubrimientos, las sociedades iletradas crearon en distintas latitudes del orbe diversos modos de comunicación y perennización de sus modos de vida, sus actividades más importantes, sus tecnologías, de sus ideas y creencias. Dibujos

34 Hay varios estudios sobre el quipu y la yupana prehispánicos y contemporáneos. Los estudios de Carlos Radicati (1990) y de Frank Salomon (2006) son buenos ejemplos para consultar sobre este tema.

35 La escritura cuneiforme de Mesopotamia y la escritura jeroglífica de Egipto aparecieron entre los años 3400 a 3100 a. C. La escritura alfabética utilizada por los fenicios data de 1800 a.C. 
y pinturas, cerámicas, músicas, cantos y danzas, tejidos y cuerdas anudadas, ceremonias colectivas de memorización, son algunas de las formas inventadas e instituidas para proyectar información de hechos más allá del momento en que se realizan. Las pinturas rupestres en las cuevas de Altamira en España y la de Lascaux y Aurignac en Francia, los petroglifos encontrados en distintas partes del mundo, las quilcas, y otras formas de expresión son probablemente las primeras formas de perennizar mensajes con fines de comunicación para la posteridad. En otras sociedades se han utilizado el arte de la cerámica para expresar la realidad de la vida cotidiana y enriquecerla con la adición de formas y colores para comunicar las características de la fauna, la flora y los detalles físicos del hombre de su tiempo. Por su lado, el arte de la danza de las sociedades antiguas y también de las modernas, que siempre viene acompañada de música, expresan mensajes simbolizados de acontecimientos míticos, religiosos, históricos, que se representan en continuidades establecidas en los eventos sociales de cada sociedad. Los tejidos, lo mismo que las cerámicas, han servido para comunicar mensajes simbolizados de las jerarquías sociales y religiosas de las sociedades y han sido otros tantos esfuerzos sociales para crear formas de escritura a través de figuras, colores y secuencias en su estructura; del mismo modo, mediante las cuerdas anudadas, como en el caso de los quipus incaicos, se crearon sistemas de almacenamiento de información y comunicación para ser interpretados en tiempos prolongados después de los sucesos acaecidos. Otras fuentes de comunicación de largo alcance en el tiempo han sido las instituciones de memorización colectiva de la historia social y las creencias de los pueblos, que tienen sus propios nombres en cada sociedad ${ }^{36}$. La escritura alfabética la inventaron los fenicios recién 1800 a. C. y la perfeccionaron los griegos desde un milenio antes de nuestra era. Antes de este acontecimiento revolucionario de la civilización, otras sociedades y culturas como los mesopotamios y egipcios ya habían inventado la escritura jeroglífica y cuneiforme quince siglos antes que los fenicios, con recursos pictográficos e ideográficos. Aún antes de ellos y paralelamente a las invenciones de estas grandes sociedades de la antigüedad, otras culturas de igual o menor desarrollo practicaban otras formas de comunicación, hoy reconocidos por los estudiosos. Transmitir conocimientos a las generaciones del futuro ha sido una preocupación constante del hombre en todas las sociedades, de acuerdo a sus niveles culturales correspondientes.

\section{La vecosina}

El otro mecanismo andino para conservar la memoria colectiva en la sociedad prehispánica era la vecosina, una institución especialmente instituida para ese fin. La vecosina no era una ceremonia sofisticada manejada por especialistas como el de los quipucamayoc, era un mecanismo eminentemente social, que tenía por finalidad reforzar la memoria colectiva, a través de los yachaj (sabedores, conocedores). Consistía en reunir a toda la gente de cada unidad poblacional (ayllus) para instruirlos en la historia social, en los valores fundamentales de la sociedad, en las ideas, creencias y ritos, que todos debían conocer y practicar. Como en otras sociedades sin escritura, la enseñanza del respeto y culto a sus dioses principales y locales tenía prioridad en estas ceremonias. Mediante la vecosina, que tenía lugar en una fecha del año, la población se reunía para escuchar las enseñanzas de los yachaj y tener memoria colectiva más o menos uniforme de los contenidos de la cultura de su sociedad. El sacerdote principal era el encargado de impartir los conocimientos y de dirigir los rituales, de preparar y de legitimar a los sacerdotes jóvenes y a las sacerdotisas encargadas de preparar la chicha y de cuidar y conservar los recursos necesarios para el culto a los dioses. Cuando los visitadores eclesiásticos recorrieron los

36 En el Perú prehispánico esta institución se llamaba Vecocina. 
pueblos del antiguo Cajatambo, la vecosina seguía funcionando como había sido instituido socialmente, como un mecanismo obligado para conservar la memoria, como lo han hecho igualmente otras sociedades ágrafas en distintos continentes ${ }^{37}$. Para Lorenzo Huertas (1981), la vecosina constituía una "regeneración periódica de la historia nativa...utilizado por los líderes religiosos indígenas para mantener vigente su propia cosmovisión”. Antonio de la Calancha dice a este respecto: "Decían los indios, que entre ellos tienen lugar de filósofos, y oficio de conservar sus memorias, y antiguas tradiciones en Quipos, cuentos, o en cantares" (Calancha, 1976: p. 831). Los mismos procesados dan cuenta del carácter y de la función social de la vecosina en sus declaraciones. Ilustramos con algunas narraciones ante el extirpador de idolatrías. Los indígenas de Hacas son, también en este tema, los que proporcionan informaciones elocuentes. Hernando Hacas Poma, el más importante sacerdote andino de esta región, dice entre otras cosas:
“...mientras hasian sus ayunos y sachrificios no entrasen en la yglesia a resar porque sus sachrificios no se les perdiesen y si el cura benia al pueblo en aquel tiempo que era fuerza para entrar en las yglesias no fuesen ni estubiessen de todo corazon sino de cumplimiento. Y asi mismo mandaba que todos los mayordomos de cofradias y alferez del pueblo de Hacas antes de haser la fiesta le diesen ofrendas y carneros de la tierra cuyes coca y lo demas para ofreser a dichos mallquis e ydolos y pedilles lisensia para poder haser las fiestas del señor San Pedro y Corpus Christi porque primero se habia de tener respeto a sus dichos mallquis e ydolos que no a los sanctos quando se juntaban todos los pueblos en la plaza a comer y beber derramasen un poco de chicha soplandola y disiendo a señores mallquis y señoras guacas y señores aguelos nuestros que estais en las yglesias bebed primero esta chicha antes que nosotros bebamos porque esta fiesta se hace en onra vuestra y este testigo y los demas biejos derramaban un poco de coca en la plaza y a la noche deste dia de fiesta hasian la vecosina que era salir todos los ayllos y parsialidades yendo delante dellos los sacerdotes y ministros de ydolos y las biejas que los acompañaban con tamborsillos tocandolos por todas las calles cantando cantares y taquies en su idioma asi usansa antigua refiriendo las historias y antiguallas de sus mallquis y guacas y entrando en las casas de los alferes de las cofradias donde bebian y se emborrachaban y hasta el amanecer estaban en este ejersisio hasiendose oposisiones I/ y bandos de unas parcialidades a otras sin dormir toda la noche en este abuso que la parsialidad o bando que primero se durmiese quedase bensido y era entre ellos como modo de ofensa que no sabian bien adorar a sus ydolos y en el bando que no se dormia quedaban victorioso ( $s$ ) y en gran estimasion porque este era rito y seremonia de su gentilidad." (Testimonio de Hernando de Hacas Poma, citado por Lorenzo Huertas, 1981: 104).

En esta narración de Hernando Hacas Poma hay varias cuestiones importantes del pensamiento y la práctica religiosa andina. En primer lugar, da cuenta de cómo los sacerdotes andinos adiestraban a los indígenas a burlar las exigencias de los curas cristianos de asistir a la iglesia para recibir las lecciones de la catequización y compartir el ritual de la misa. Les enseñaban a no entrar a la iglesia cristiana cuando festejaban sus fiestas y ceremonias religiosas dedicadas a sus dioses locales o regionales. Pero cuando el cura cristiano obligaba asistir a las misas dominicales, no lo hiciesen “...de todo corazón sino de cumplimiento". La resistencia a la cristianización tiene aquí un ingrediente especial, el de simular la conversión a la que aspiraban los curas doctrineros, mediante la oposición de la conciencia de los naturales. Del mismo modo, los sacerdotes andinos adiestraban y

\footnotetext{
37 En la novela Raíces de Alex Haley, los informantes de la familia de Kunta Kinte de Gambia, pudieron establecer con precisión mediante el uso de la memoria colectiva de seis generaciones, quienes fueron los padres de este joven que en 1767 fue apresado como esclavo y conducido a las plantaciones de algodón de los Estados Unidos.
} 
concientizaban a los funcionarios de las fiestas - mayordomos y alfereces- pedir licencia o permiso a sus divinidades, mediante las ceremonias gentilicias de rigor, ofreciendo carneros, coca, sebo, cuyes: “...a dichos ydolos y mallquis pedilles lissensia para poder haser la fiesta del señor San Pedro y Corpus Christi..." En efecto, desde los tiempos de la organización de las reducciones de indios durante el virreinato de Francisco de Toledo, en Acas se había instituido la fiesta patronal de San Pedro, como sigue siéndolo hasta hoy. La fiesta de Corpus Christi fue impuesta en todo el dominio español, en sustitución y oposición de la fiesta principal organizada por los Incas, dedicada al padre $\operatorname{sol}^{38}$. El Corpus Christi ha prevalecido con esplendor en Acas y en muchos pueblos andinos hasta las primeras décadas del siglo XX, en la actualidad se mantienen en pocas localidades y en esos lugares siguen concurriendo las más variadas expresiones de danzas y de música. Otra manifestación de la resistencia religiosa consistía en esconder y enterrar dentro de la iglesia cristiana algunos de sus ídolos sagrados. Por eso, cuando hacían las ceremonias de las "lisensias" a sus deidades les invocaban “... señores mallquis señores guacas señores aguelos nuestros que estais en las yglesias bebed primero esta chicha antes que nosotros bebamos porque esta fiesta se hace en onra vuestra..." Derramaban chicha en forma ritual para que les perdone la obligación de entrar a la iglesia cristiana.

Otras informaciones de Hernando Hacas Poma tienen que ver con la ceremonia y el significado de la vecosina. Esta ceremonia estaba dedicada al avivamiento, a la afirmación y a la concientización de la historia social del grupo étnico y al pensamiento religioso del pueblo indígena. Tal como lo cuenta este testigo, durante la ceremonia de la vecosina, se reunían todos los yllus y las parcialidades en la plaza. Durante la gran procesión de la gente por la plaza, el sacerdote principal y los secundarios iban adelante. Eran acompañados por las mujeres ancianas que cantaban taquis “...refiriendo las historias y antiguallas de sus mallquis y guacas...", al ritmo de las tinyas que ellas mismas tocaban. Los taquis cantados por las ancianas eran la reafirmación de los discursos de enseñanza y concientización de los sacerdotes principales. Hacas Poma era en Acas el más prestigiado sacerdote, al nivel de Domingo Rimachi de Pimachi o de Andrés Chaupis Yauri de Otuco. Presidía los rituales dedicado a los dioses y era el maestro de todas las ceremonias colectivas. Durante la noche del día dedicado a la vecosina, todos amanecían realizando rituales, libaciones, cantos, bailes y juegos. La norma consistía en una competencia entre las parcialidades de no quedarse dormidos en toda la noche: las parcialidades que amanecían en actividad eran los ganadores y recibían la aceptación y "estimasion" de las deidades, porque resistir el sueño era signo de fe y de pleitesía a sus divinidades, quedarse dormidos era una derrota y al mismo tiempo una "ofensa" a sus dioses.

La otra versión relativa al fomento de la memoria colectiva es el testimonio de Francisco Pomayaltas Caldeas, también del pueblo San Pedro de Hacas, del ayllu de Tacas, 46 años de edad. Es igualmente interesante porque explica sobre la vecosina y también da nuevos datos que Hacas Poma no explicita en su declaración. Pomayaltas declara ante el visitador eclesiástico Bernardo de Noboa, el 5 de enero de 1657 en estos términos:

“... todos los ministros de ydolos salen con las mugeres de todos los ayllus con tamborcillos en bandos por todas las calles bailando y belando con este ejersisio hasta el amanecer y entrando en las casas de los pendoneros y bebiendo y si algun bando destos se duerme antes de amaneser disen quedan bencidos corridos y afrentados porque no an sabido hacer fiesta a sus ydolos ni mocharlos pues se durmieron y los que bailaron asta el amanecer sin dormir quedan victoriosos por aber belado toda la noche haciendo fiesta a sus ydolos y este rito llaman la Vecosina y en aquellos

38 El Inti Raimi fiesta jubilar del solsticio de invierno, dedicado al Sol, coincidente con el comienzo de las cosechas fue sustituido por la fiesta Corpus Christi del catolicismo europeo. 
cinco dias de ayunos y confesiones bio este testigo que los dichos ministros de ydolos enseñaban a todos los yndios que adorasen al sol porque es el padre y que crio a los hombres y a la luna por criadora y madre de las mugeres y al luzero de la mañana que llaman chachaguara por padre y criador de los curacas y a las dos estrellitas pequeñas que andan juntas que llaman chuchucoillor por criadora de los niños que nacen dos en un vientre y a las siete cabrillas que llaman uncuicoillor porque no se yelen sus chacras y no haya enfermedades... “(Expediente $\mathrm{N}^{\circ}$ XI del legajo 6 del Archivo Arzobispal de Lima).

Hay en las declaraciones de los dos sacerdotes de Hacas similitud en la narración sobre la ceremonia de la vecosina. Los dos explican la participación masiva de las parcialidades y ayllus en los rituales, que duran cinco días continuos, bajo la conducción de los sacerdotes "ministros" y de la algarabía de los bailes y de la música cantada por las ancianas, que tañen sus tamborcillos, y de la visita que realizan a los "mayordomos" o a los "pendoneros" donde hacían las libaciones de la chicha sagrada. Es decir, declaran casi uniformemente sobre el acontecimiento de avivamiento de la memoria colectiva, manteniéndose en movimiento toda la noche para no quedar "afrentados", compitiendo en grupos de no quedarse dormidos en honor a la adoración y pleitesía de sus divinidades y del espíritu de sus antepasados los mallquis. Lo nuevo e interesante en las declaraciones de Francisco Pomayaltas es que en esos cinco días de "ayunos y confesiones", los sacerdotes andinos se dedican a enseñar en actos colectivos "a todos los yndios" adorar y rendir culto conciente a sus divinidades. Según el testigo estas son las divinidades, jerárquicamente entendidas por él:

\section{Dioses celestes}

Al Sol

A la luna

Al Lucero de la mañana (Venus)

A las dos estrellitas "chuchucoillor"

A las siete cabrillas "uncuicoillor"

\section{Por ser padres creadores de:}

Por ser el padre creador de los hombres.

Por ser la madre creadora de las mujeres.

Por ser padre creador de los curacas.

Por ser padre creador de gemelos.

Para que no se hielen las cementeras y no haya enfermedades.

Para este testigo de Hacas, los dioses del firmamento son los creadores de seres humanos, de los mandones de ayllus y son también controladores de los fenómenos de la naturaleza como de las heladas que dañan a las cementeras y a las enfermedades que afectan a la salud de los seres humanos. Cada divinidad celeste ha tenido una función específica por la que son adorados y reciben de ellos honores según sus tradiciones construidas en el tiempo. En la mentalidad de los acasinos de la época de las visitas eclesiásticas este grupo de divinidades responde a una categoría de dioses andinos, que en su conjunto son de varios tipos. Los dioses del firmamento corresponden a la ideología que viene de los huaris y luego impuesta por los incas, de cuyo contenido Pomayaltas es consciente y asiduo practicante. El dios rayo (Libiac), del que descienden los llacuaces es otra categoría de divinidad regional. Los héroes fundadores que están presentes en sus machayes (mallquis, camaquenes) le siguen en jerarquía. Otro conjunto de divinidades menores, concretamente locales, tales como los conopas de plantas y de animales, los ídolos de las chacras y manantiales, el yucyuc, la mama sara, el misha sara, constituyen para la mentalidad de los yachaj de Cajatambo el complejo mundo del pensamiento religioso andino. En ellos se expresa plenamente el politeísmo prehispánico, a los que les rinden pleitesía dos veces al año: en pocoi mita (época de siembra) y en carhua mita (tiempo de cosechas). Es decir, al comienzo del año agrario del mes de diciembre, cuando se siembran las sementeras y al medio año, en el mes de junio, cuando los sembríos empiezan a madurar y comienza la cosecha; en otros términos: en el solsticio de verano y en el solsticio de invierno. Unos dioses están en las alturas del firmamento y pueden verlos en el día y en las noches; sus vidas están adecuadas 
a sus reflejos y a sus movimientos cíclicos; otros dioses conviven en cay pacha (esta tierra) con ellos, interactuando en sus vidas, en sus quehaceres, en sus aspiraciones y sus luchas. La rica mitología de los griegos fundadores de la cultura occidental se emparenta con la no menos compleja y extraordinaria mitología de la sociedad andina. Todas las cosas, incluyendo su propia existencia, están explicadas por estos memorables discursos, que la vecosina se encargaba de reforzarla y perennizarla a fin de que los grupos humanos mantengan vivas sus identidades culturales.

\section{Bibliografía}

AMAT OLAZÁBAL, Hernán

1978 "Los yaros destructores del imperio Huari”, en Actas del III Congreso Peruano del Hombre y la Cultura Andina, tomo II. Lima.

ÁNGELES CABALLERO, César

1988 Folklore peruano, tomo I. Lima.

BARRIONUEVO, Alfonsina

1981 Lima: el valle del dios que hablaba. Lima: Editorial Universo.

CALANCHA, Fray Antonio de

1976 Crónica moralizada (5 tomos). Lima: Universidad Nacional Mayor de San Marcos.

CARDICH, Augusto

1975 "Agricultores y pastores de Lauricocha y límites superiores del cultivo", en Revista del Museo Nacional, tomo XLI, Lima.

1981 Dos divinidades relevantes del antiguo panteón centro andino: Yana Ramán o Libiac Cancharco y Rayguana. Argentina: Universidad Nacional de La Plata, (Serie monográfica 1).

CHOY, Emilio

1958 "De Santiago matamoros a Santiago mataindios", en Revista del Museo Nacional, tomo XXVII, Lima.

DOMÍNGUEZ CONDEZO, Víctor

2003 Danzas e identidad nacional. Lima: Universidad de Huánuco, Editorial San Marcos.

DUVIOLS, Pierre

1973 "Huari y Llacuaz, pastores y agricultores: un dualismo de oposición y complementariedad", en Revista del Museo Nacional, tomo XXXIX, Lima.

1986 Cultura andina y represión. Proceso de visitas de idolatrías y hechicerías Cajatambo, siglo XVII. Cusco: Centro de Estudios Rurales Andinos "Bartolomé de las Casas". (Segunda edición: PUCP e IEP, Lima, 2003).

ELIADE, Mircea

1968 El mito del eterno retorno. Buenos Aires: Emecé editores.

FONSECA MARTEL, César

1973 Sistemas económicos andinos. Lima: Universidad Nacional Mayor de San Marcos.

GARCILASO DE LA VEGA, Inca

1963 Los comentarios reales de los incas. Madrid: Biblioteca de autores españoles.

GÓMEZ ALARCÓN, Arturo (Compilador)

Mitología andina: Dioses, mitos y leyendas, http://diosesdelperu.blogspot.com 
HUERTAS VALLEJOS, Lorenzo

1981 La religión en una sociedad rural andina (Siglo XVII). Perú: Universidad Nacional San Cristóbal de Huamanga, Ayacucho.

KRAMER, Samuerl

1962 La historia empieza en Súmer. Barcelona.

KINSL, Hans

1936 "La cordillera de Huayhuash (Perú)", en Revista Geográfica, Lima (Traducido del alemán por Carlos Nicholson).

KIRK, G. S.

1973 El mito: su significado y funciones en las distintas culturas. Barcelona: Barral editores.

KRICKEBERG, Walter (1995). Mitos y leyendas de los aztecas, incas, mayas y muiscas, Fondo de Cultura Económica, México (Octava reimpresión).

LEVI-STRAUSS, Claude

1964 El pensamiento salvaje. México: Fondo de Cultura Económica.

1964 Mitológicas I: Lo crudo y lo cocido, FCE, México, 1968; Mitológicas II: De la miel a las cenizas, FCE, México, 1971; Mitológicas III: El origen de las maneras de mesa, Siglo XXI editores, México, 1976; Mitológicas IV: El hombre desnudo, Siglo XXI, México, 1981.

1968 Antropología estructural. Buenos Aires: Eudeba.

1990 Mito y significado. Madrid: Alianza Editorial.

MARTÍNEZ CANO, Melinda

2005 "Parco: un pueblo asentado sobre aguas cristalinas", en revista Agua N. . 2. Perú: Huancayo.

MOROTE BEST, Efraín

1988 Aldeas sumergidas: cultura popular y sociedad en los Andes. Cusco: Centro de Estudios Rurales Andinos "Bartolomé de las Casas".

MURRA, John V.

1975 "Las etno-categorías de un khipu estatal", en Formaciones económicas y políticas en el mundo andino. Lima: Instituto de Estudios Peruanos.

PEASE, Franklin

1979 "Mitos andinos: una introducción”, Anuario de Estudios Americanos tomo XXVII. España: Sevilla.

RADICATI DE PRIGMELIO, Carlos

1979 El sistema contable de los incas: yupana y quipu. Lima: Librería Studium.

1990 "Hacia una tipificación de los quipus", en Carol Mackey et. al. (Ed.). Quipu y yupana. Colección de escritos. Lima: CONCYTEC.

ROBLES MENDOZA, Román

1978 "La religión cristiana en el proceso de colonización del mundo andino: destrucción y supervivencia de las prácticas religiosas prehispánicas en Mangas (CajatamboBolognesi)", en María Coth de Paredes y Amalia Castelli (Comp.), Etnohistoria y antropología andina. Lima.

2000 La banda de músicos: Las bellas artes musicales al sur de Ancash. Lima: Universidad Nacional Mayor de San Marcos.

ROBLES G., Wilelmo

1959 Narraciones, danzas y acertijos (del folklore huamaliano), Lima.

SALOMON, Frank

2006 Los quipucamayos. El antiguo arte del khipu en una comunidad campesina moderna. Lima: IEP, IFEA, 
SILVA, Miguel Ángel

2008 "El mito del dios Vichama”, en: Gómez Alarcón, Arturo. Dioses, mitos y leyendas, http://diosesdelperu.blogspot.com

VALCÁRCEL, Rosina

1988 Mitos: dominación y resistencia andina. Lima: Universidad Nacional Mayor de San Marcos.

YAURI MONTERO, Marcos

2000 Leyendas ancashinas: toda la magia y el encanto del Ancash milenario, $6 .{ }^{a}$ edic.: Lima (Primera edición: 1961). 